Published in final edited form as:

Prog Neurobiol. 2012 October ; 99(1): 1-14. doi:10.1016/j.pneurobio.2012.06.001.

\title{
CACNA1C $\left(\mathrm{Ca}_{\mathrm{v}} 1.2\right)$ in the pathophysiology of psychiatric disease
}

\author{
Shambhu Bhat ${ }^{a}$, David T. Dao ${ }^{a}$, Chantelle E. Terrillion ${ }^{b}$, Michal Arad ${ }^{a}$, Robert J. Smith ${ }^{a}$, \\ Nikolai M. Soldatov ${ }^{d}$, and Todd D. Gould ${ }^{a, b, c,{ }^{*}}$ \\ ${ }^{\text {aDepartment }}$ of Psychiatry, University of Maryland School of Medicine, Baltimore, MD, United \\ States \\ bProgram in Neuroscience, University of Maryland, Baltimore, MD, United States \\ 'Department of Pharmacology, University of Maryland School of Medicine, Baltimore, MD, United \\ States \\ dHumgenex, Inc., Kensington, MD, United States
}

\begin{abstract}
One of the most consistent genetic findings to have emerged from bipolar disorder genome wide association studies (GWAS) is with CACNA1C, a gene that codes for the $\mathrm{a}_{1 \mathrm{C}}$ subunit of the $\mathrm{Ca}_{\mathrm{v}} 1.2$ voltage-dependent L-type calcium channel (LTCC). Genetic variation in $C A C N A 1 C$ have also been associated with depression, schizophrenia, autism spectrum disorders, as well as changes in brain function and structure in control subjects who have no diagnosable psychiatric illness. These data are consistent with a continuum of shared neurobiological vulnerability between diverse-Diagnostic and Statistical Manual (DSM) defined-neuropsychiatric diseases. While involved in numerous cellular functions, $\mathrm{Ca}_{\mathrm{v}} 1.2$ is most frequently implicated in coupling of cell membrane depolarization to transient increase of the membrane permeability for calcium, leading to activation and, potentially, changes in intracellular signaling pathway activity, gene transcription, and synaptic plasticity. $\mathrm{Ca}_{\mathrm{v}} 1.2$ is involved in the proper function of numerous neurological circuits including those involving the hippocampus, amygdala, and mesolimbic reward system, which are strongly implicated in psychiatric disease pathophysiology. A number of behavioral effects of LTCC inhibitors have been described including antidepressant-like behavioral actions in rodent models. Clinical studies suggest possible treatment effects in a subset of patients with mood disorders. We review the genetic structure and variation of $C A C N A 1 C$, discussing relevant human genetic and clinical findings, as well as the biological actions of $\mathrm{Ca}_{\mathrm{v}} 1.2$ that are most relevant to psychiatric illness.
\end{abstract}

\section{Keywords}

Calcium channel; $C A C N A 1 C$, Genome wide association study; Bipolar disorder; Depression; Schizophrenia; Psychiatric genetics

\section{CACNA1C in mental disorders}

While a number of medications are used for the treatment of psychiatric disorders, the majority were developed based upon efficacy to reduce symptoms rather than to eliminate pathological processes. Current treatments are inadequate for many patients as recurrence is

(C) 2012 Elsevier Ltd. All rights reserved.

*Corresponding author at: Department of Psychiatry, University of Maryland School of Medicine, Rm. 934D MSTF, 685W. Baltimore St., Baltimore, MD 21201, United States. Tel.: +1 410706 5585; fax: +1 410706 4002. gouldlab@me.com (T.D. Gould). 
common and the full clinical effects are often not obtained until after months of treatment. Despite these well-known inadequacies, improvements have been slow in coming largely due to a dearth of understanding regarding pathophysiology. This lack of knowledge has prevented the development of treatments specific for the underlying disease mechanisms of psychiatric illness.

Many neuropsychiatric disorders are highly heritable, indicating that genetics is certain to have a role in pathogenesis. For example, the individual heritability of bipolar disorder, major depression, and schizophrenia is estimated to be approximately $70-90 \%, 40-50 \%$, and 80-85\%, respectively (Cannon et al., 1998; Cardno and Gottesman, 2000; Kendler and Prescott, 1999; Kieseppä et al., 2004; McGuffin et al., 1996, 2003). There is also evidence for shared familial susceptibility between these three Diagnostic and Statistical Manual (DSM)-IV-defined disorders, and in particular between bipolar disorder and depression, and bipolar disorder and schizophrenia (Berrettini, 2003; Demjaha et al., 2011; Gottesman et al., 2010; Lichtenstein et al., 2009; McGuffin et al., 2003). These epidemiological data are supported by the more recent findings that specific genetic risk variants cross these diagnostic boundaries as well (Chubb et al., 2008; Maier, 2008; Williams et al., 2011). While there is a credible prediction that identifying susceptibility genes will eventually lead to targeted 'cure therapeutics' (Insel and Scolnick, 2006), there first remains a critical need to definitively identify such genes and to subsequently understand the functional consequences of the associated genetic variations (Fig. 1). However, identifying underlying susceptibility genes that are associated with psychiatric disorders in multiple populations has proven to be difficult due to a number of factors including less than adequate sample sizes, the polygenetic and multifactorial nature of the disorders, uncertainty or lack of precision in the diagnoses, and significant overlap both in terms of symptoms and likely pathophysiology as well.

However, encouraging results have emerged recently as the results of adequately powered genome-wide association studies (GWAS) have converged to implicate specific genetic polymorphisms. One gene in which such genetic polymorphisms have been identified is CACNA1C, which codes for the pore-forming $\mathrm{a}_{1 \mathrm{C}}$ subunit of the L-type voltage-gated calcium channel (LTCC), referred to as $\mathrm{Ca}_{\mathrm{v}} 1.2 . \mathrm{Ca}_{\mathrm{v}} 1.2$ couples transient activation of inward calcium current to transcriptional regulation and plays an important role in dendritic development, neuronal survival, synaptic plasticity, memory formation, learning, and behavior (Barad, 2003; Dudkin et al., 1990; Kobrinsky et al., 2011; Moosmang et al., 2005; Shibasaki et al., 2010; West et al., 2001; Wheeler et al., 2008; White et al., 2008; Yoshii and Watabe, 1994).

The LTCC family consists of four distinct members referred to as $\mathrm{Ca}_{\mathrm{v}} 1.1-\mathrm{Ca}_{\mathrm{v}} 1.4$ (Catterall, 2011). $\mathrm{Ca}_{\mathrm{v}} 1.2$ is the primary LTCC expressed in the mammalian brain. In the mouse brain, quantitative polymerase chain reaction (qPCR) of RNA transcripts revealed that $\mathrm{Ca}_{\mathrm{v}} 1.2$ accounts for approximately $85 \%$ of the LTCCs with $\mathrm{Ca}_{\mathrm{V}} 1.3$ accounting for most of the remainder (Sinnegger-Brauns et al., 2009). A functional $\mathrm{Ca}_{\mathrm{v}} 1.2$ channel consists of three subunits: transmembrane $\mathrm{a}_{1 \mathrm{C}}(C A C N A 1 C)$ and $\mathrm{a}_{2} \delta$ (encoded by $C A C N A 2 D-1,2$ or 3 ) as well as intracellular $\beta$ (encoded by $C A C N B 1-4$ genes) and calmodulin (CaM) (Dolphin, 2009). The major characteristics of the $\mathrm{Ca}_{\mathrm{v}} 1.2$ channel such as voltage-sensing, ion selectivity, and pharmacological responses associated with binding of calcium channel blockers are encoded by $C A C N A 1 C$. Auxiliary $\mathrm{a}_{2} \delta, \beta$ and $\mathrm{CaM}$ are involved in regulation of expression and modulating select properties of $\mathrm{Ca}_{\mathrm{v}} 1.2$.

There is evidence that functional mutations in the $C A C N A 1 C$ gene predispose to autism spectrum disorders. A rare human autosomal-dominant multisystem disorder, Timothy Syndrome, presenting with arrhythmias, webbed digits, congenital heart disease, and autism 
spectrum symptoms is associated with a mutation in the exon 8A splice variant of CACNA1C that comprises about $23 \%$ of $\mathrm{Ca}_{\mathrm{v}} 1.2$ in heart and brain (Splawski et al., 2004). It has been demonstrated that Timothy Syndrome is associated with the G406R mutation in the cytoplasmic end of the exon 8A-coded transmembrane segment IS6. This mutation greatly reduces voltage-dependent inactivation of the calcium channel with little effect on calciumdependent inactivation (Barrett and Tsien, 2008), and thus may potentially cause a pathogenic calcium overload in cardiac and neuronal cells. An analogous mutation in alternative exon 8 (mutually exclusive with exon $8 \mathrm{~A}$ ), G402S, and a corresponding reduction in voltage-dependent inactivation were observed in $\mathrm{Ca}_{\mathrm{v}} 1.2$ of an individual with a severe Timothy Syndrome variant (Splawski et al., 2005, 2004). Taken together, these results show pathogenic effect of naturally occurring gain-of-function mutations probably affecting $\mathrm{Ca}_{\mathrm{v}} 1.2$ molecular determinant(s) of slow inactivation (Depil et al., 2011; Shi and Soldatov, 2002).

Interestingly, prior to GWA approaches $C A C N A 1 C$ was considered a potential candidate gene for bipolar disorder. As reported in 2002, CACNA1C was included in a family based association study (470 parent-proband trios) of 76 candidate genes and was one of two genes (the other being brain derived neurotrophic factor $(B D N F)$ ) where a single nucleotide polymorphism (SNP) in $C A C N A 1 C$ was found to be nominally associated with a bipolar disorder diagnosis (Sklar et al., 2002). However, the association with CACNA1C did not survive the confirmation analysis in a separate cohort, though the association with $B D N F$ did (Sklar et al., 2002). In hindsight this lack of replication was likely related to the genotyped synonymous (silent) SNP (rs72552065) being located in exon 44, approximately $450 \mathrm{~kb}$ downstream from the SNPs subsequently implicated by GWA studies conducted later on.

In a manner not biased by the previous results, in 2008 Sklar et al. reported the results of a GWA study of 1461 bipolar disorder and 2008 control subjects combined with the results of the Wellcome Trust Case-Control Consortium GWA study (Burton et al., 2007), and reported that the strongest signal $\left(p=1 \times 10^{-4}\right)$ of association from these combined samples were from a SNP within the $C A C N A 1 C$ gene (rs1006737) (Sklar et al., 2008). The accepted standard for GWA significance is $5 \times 10^{-8}$ (Pe'er et al., 2008). Subsequent studies with increasingly larger sample sizes have since confirmed this finding (Ferreira et al., 2008; Keers et al., 2009). See Table 1, which details the genetic evidence associating CACNA1C with psychiatric disorders, and includes p values for all GWA studies, as well as odds ratios. The strongest implicated SNP in these early GWA studies was rs1006737. Most recently, the results of the Psychiatric Genetics Consortium (PGC) Bipolar Working Group comparing 11,977 bipolar disorder subjects and 51,672 controls identified another SNP (rs4765913) in $C A C N A 1 C$ as the most significant finding in that study, at a significance level of $p=1.52 \times 10^{-8}$ (Sklar et al., 2011).

Many of the studies described above utilized overlapping patient and control populations, which increased with subsequent studies. As the population size increased the strength of association increased in these studies and the first strong association with bipolar disorder was observed at rs 1006737 . However, subsequent GWA studies with larger population size have identified significant associations with other SNPs. Therefore, while overlapping populations in successive studies possibly contributed to identifying rs1006737 as a candidate susceptibility SNP associated with bipolar disorder, they have not always resulted in consistent replication of this particular SNP. While the inability to fully replicate specific GWAS-identified SNPs in all the studies is a concern, the consistency with which GWAS signals are identified within the same general region (intron 3) of CACNA1C indicates the likely importance of the gene in bipolar disorder psychopathology (Fig. 2). 
The clinical genetic association of $C A C N A 1 C$ with mental disorders appears to be broader than for bipolar disorder only. Recent studies have established an association of CACNA1C genotype with schizophrenia (Bigos et al., 2010; Nyegaard et al., 2010) and major depression disorder (Casamassima et al., 2010b; Shi et al., 2011). Several studies have also implicated $C A C N A 1 C$ in combined analysis including distinct DSM-defined psychiatric disorders. For example, Green et al. (2010) conducted a GWAS with patients diagnosed with unipolar recurrent major depression $(N=1196)$, bipolar disorder $(N=1868)$ and schizophrenia $(N=479)$ compared to 15,316 nonpsychiatric control subjects. The authors found that the previously reported bipolar disorder risk SNP (rs1006737) conferred risk of schizophrenia and early recurrent major depression. The authors also noted that the association of rs1006737 with bipolar disorder was strengthened when they combined their data with that from the previous study by Ferreira et al. (2008). Recently, in a combined analysis of bipolar and schizophrenic $(n=16,373)$ patients compared to control $(n=14,044)$ subjects, rs4765905 located within $C A C N A 1 C$ was implicated as the top statistical hit $(7.0 \times$ $10^{-9}$ ) (Ripke et al., 2011). Another recent combined analysis of bipolar disorder and schizophrenia data sets revealed significant association with CACNA1C SNP rs4765913 (Sklar et al., 2011). Most recently Hamshere et al. (2012), reported that rs4765905 achieved genome wide significance for an association with schizophrenia after combining additional subjects with the analysis by Ripke et al. (2011). rs4765905 is in complete linkage disequilibrium (LD), defined as the occurrence of genotypes at two loci that is significantly different than by chance alone, with rs $1006737\left(D^{\prime}=1.0, t^{2}=1.0 ; \mathrm{LD}\right.$ is denoted by $D^{\prime}$, or a correlation coefficient $r^{2}$, which both range from 0 to 1, with 1 indicating perfect LD) (Hill, 1974; Lewontin, 1964, 1988; Reich et al., 2001; Slatkin, 2008).

In terms of major depression, a meta analysis of two separate earlier GWA studies of bipolar and major depressive disorder patients, the CACNA1C SNPs rs1006737 and rs7297582 were found to reach a genome wide significance when both bipolar and unipolar mood disorders were combined (Liu et al., 2011). Further support for the involvement of CACNA1C in depression was provided by Dao et al. who reported that two SNPs in intron 3 (rs2370419 and rs2370411) showed significantly increased risk of illnesses in females, but not males, for bipolar and major depression disorder (Dao et al., 2010). This study used the GWAS data generated earlier from the National Institute of Mental Health-Genetics Initiative Bipolar Disorder (NIMH-GIBD) and Genetics of Recurrent Early-onset Major Depression (GenRED) consortium datasets, consisting of 2021 mood disorder cases and 1840 controls.

Thus, the results of a number of recently published studies in multiple populations have repeatedly linked polymorphisms in $C A C N A 1 C$ to multiple psychiatric disease diagnoses and indicate that associations between $C A C N A 1 C$ polymorphisms are not unique to one disorder (Table 1). The evidence implicates $C A C N A 1 C$ as currently the most statistically robust finding when combining multiple psychiatric disease categories. While the most statistically robust $C A C N A 1 C$ associations are in bipolar disorder, as compared to depression and schizophrenia, these data suggest that $C A C N A 1 C$ belongs to a class of shared susceptibility factors. These data support a conclusion that diagnostic categories are not appropriate for delineating the downstream effects of genes on behaviors.

Thus, $C A C N A 1 C$ is a common risk factor for which genetic evidence indicates that the identified intronic SNPs have significant correlation with pathological behaviors. The associated genetic changes in $C A C N A 1 C$ likely act through a common developmental and/ or physiological process of central nervous system function in a manner that is common across current diagnostic categories, and at a level upstream from symptoms. Consistent with this hypothesis, as we discuss in more detail later, recent reports have associated the most consistently reported disease-associated SNP (rs1006737) with variations in brain 
structure and function in psychiatrically healthy human subjects. However, the mechanisms underlying how genetic changes in $C A C N A 1 C$ modify risk for developing psychiatric disorders are unclear. Indeed, defining the implications of such $C A C N A 1 C$ genetic change in a context relevant to psychiatric disorder pathophysiology is essential.

\section{CACNA1C genetic variation}

CACNA1C is located on the short arm of chromosome 12p13.3, spanning an approximately $6.45 \mathrm{Mb}$ genomic region (Gene ID 775). The gene consists of at least 55 exons (Soldatov, 1994), which span an approximately $740 \mathrm{~kb}$ region. A number of SNPs in CACNA1C, concentrated within the large $328.5-\mathrm{kb}$ intron 3 , have been linked to psychiatric illness (Table 1), with limited information currently available regarding functional consequences. The locations of these SNPs within the gene are detailed in Fig. 2. Given their location in a non-coding region of the gene, they are not expected to directly interfere with the structurefunctional properties of $\mathrm{Ca}_{\mathrm{v}} 1.2$ (e.g., as in the case of G402S in Timothy syndrome). However, a likely consequence of intronic variation is regulation of expression of the channel. Beginning to address these questions Bigos et al. reported an association between total expression of $C A C N A 1 C$ and a SNP in complete LD with rs 1006737 in an earlier microarray based expression analysis of postmortem brains (Bigos et al., 2010). It is currently not known whether this effect is constant throughout development, and in what specific tissues or brain regions.

A few studies have assessed for an imbalance in the relative expression of the two CACNA1C alleles, referred to as allelic expression imbalance (AEI) (Yan et al., 2002). Estimating AEI involves measuring the relative expression of the alleles of a given gene within the same cell or the same tissue sample. This approach minimizes the non-allelic factors, such as environmental exposures, that can modify gene expression and maximizes the identification of effects caused by variation in individual alleles. While AEI for CACNA1C was not identified in cardiovascular tissues from transplant recipients (Johnson et al., 2008), lymphoblastoid cell lines from normal controls did show AEI at some SNPs (Quinn et al., 2010). Interestingly, these other SNPs are not in LD with SNPs identified in GWA studies (Quinn et al., 2010).

It is known that the $C A C N A 1 C$ transcript is subject to extensive alternative splicing that potentially could generate thousands of splice variants. However, complementary DNA (cDNA) cloning experiments have yielded a much more limited number of partially overlapping sequences that comprises of, at a minimum, 40 known splice variants (Tang et al., 2004; Tiwari et al., 2006) of which at least 23 are protein coding (National center for Biotechnology information database). The high degree of variation is due to several different mechanisms of alternative splicing, including splicing of exons at alternate junctions, the presence of mutually exclusive exons, exons that either splice as alternate exons or at alternate donor sites, and through utilization of alternate promoters (Abernethy and Soldatov, 2002; Dai et al., 2002; Pang et al., 2003; Perez-Reyes et al., 1990a,b).

CACNA1C is expressed in many tissues in the human body across various developmental stages (Pang et al., 2003). Its expression has been observed in embryonic, fetal, infant, and adult stages. The gene is widely expressed in the brain (especially hippocampus and thalamus), cerebral arteries, whole heart, cardiac muscle and fibroblasts (Narayanan et al., 2010; Perez-Reyes et al., 1990b; Powers et al., 1991; Schultz et al., 1993; Soldatov, 1992). Expression of the transcripts are species- and tissue-dependent, developmentally regulated and is affected by pathophysiological conditions (Barad, 2003; Brillantes et al., 1994; Feron et al., 1994; Hofmann et al., 1994; Liao et al., 2007; Obermair et al., 2004; Tang et al., 2009; Tiwari et al., 2006). The majority of known splice variation, which predominates on the 3 ' 
end of the gene, is not in proximity to genetic changes associated with mood disorders and schizophrenia (Fig. 2). However, the diversity in phenotypes of $C A C N A 1 C$ splice variants is relevantin studying the functioning of the gene in psychiatric disorders and may have importance in understanding disease mechanisms (Wang et al., 2006). It also provides avenues to interrogate potential targets for drug development and selective modification of physiological functioning.

\section{3. $\mathrm{Ca}_{\mathrm{v}} 1.2$ calcium channel}

The $\mathrm{Ca}_{\mathrm{v}} 1.2$ a $1 \mathrm{C}$ subunit consists of four repeating domains (I-IV), each with six transmembrane $a$ helical segments (S1-S6) that are connected by intra- and extra-cellular loops (Abernethy and Soldatov, 2002; Mikami et al., 1989; Tanabe et al., 1987) as well as a long $\mathrm{C}$-terminus and shorter $\mathrm{N}$-tail that both point to the cytoplasm. In neurons of the central nervous system, $\mathrm{Ca}_{\mathrm{v}} 1.2$ channels are located primarily in the postsynaptic dendritic processes and somata, and are distributed throughout the dendritic tree (Leitch et al., 2009). This somatodendritic localization of $\mathrm{Ca}_{\mathrm{v}} 1.2$ places it at a key position to couple neuronal excitation with $\mathrm{Ca}_{\mathrm{v}} 1.2$-mediated $\mathrm{Ca}^{2+}$ signaling that modulates gene transcription making $\mathrm{Ca}_{\mathrm{v}} 1.2$ an effective regulator of signaling pathways. The widespread downstream effects of $\mathrm{Ca}_{\mathrm{v}} 1.2$ and other LTCCs are achieved through $\mathrm{CaM}$ associated with CaM-binding sites situated in the $a_{1 \mathrm{C}} \mathrm{C}$-terminal tail (Halling et al., 2005) and some other signaling molecules localized probably close to the channel pore. $\mathrm{CaM}$ is an essential component of the mechanism of calcium-dependent inactivation guarding against calcium overloading during long action potentials (Zuhlke et al., 1999). Other data suggest that calcium binding protein-1 (CaBP1) may also be involved in regulation of $\mathrm{Ca}_{\mathrm{v}} 1.2$ activity (Oz et al., 2011; Zhou et al., 2004). A key downstream mechanism of calcium signaling is calcium-induced intracellular calcium release (CICR) through ryanodine receptors (RyR), which has been widely demonstrated in cardiac and skeletal muscle LTCCs. CICR mediated by ryanodinesensitive stores in hippocampal and other central neurons is not affected by calcium channel blockers (Sandler and Barbara, 1999), although there is some data indicating that neuronal LTCCs may in fact mediate CICR (Kim et al., 2007; Kolarow et al., 2007).

While the full details of LTCC signaling to the nucleus are yet to be elucidated, studies have extensively linked LTCC-mediated calcium influx to the $\mathrm{Ca}^{2+} / \mathrm{CaM}$-dependent protein kinases (CaMK) cascade and the mitogen-activated protein kinase (MAPK) pathway. Immunoprecipitation studies have found that $\mathrm{Ca}_{\mathrm{v}} 1.2$ is closely associated with CaMKII that is tethered to the channel by a binding site on the $\mathrm{COOH}$ terminus of the $\mathrm{a}_{1 \mathrm{C}}$ subunit in heart tissue (Hudmon et al., 2005) and to the $\mathrm{Ca}_{\mathrm{v}} \beta_{1}$ and $\beta_{2}$ subunits in forebrain tissue (Abiria and Colbran, 2010). Such molecular association may be spatially and temporally flexible because $\mathrm{Ca}_{\mathrm{v}} \beta$ subunits tend to form homo- and hetero-oligomers at the functional $\mathrm{Ca}_{\mathrm{v}} 1.2$ calcium channels (Lao et al., 2010). This localization of CaMKII close to the channel has been shown to be important in integrating and coupling local calcium increases to cyclic adenosine monophosphate (cAMP) response element binding protein (CREB)-dependent gene transcription (Wheeler et al., 2008). There is also evidence that CaM bound to LTCCs is particularly effective in activating the MAPK cascade leading to sustained CREB phosphorylation (Dolmetsch et al., 2001). For example, recent work has shown that inhibition of extracellular signal-regulated kinases (Erk) 1 and 2 increases synaptic vesicle release by increasing the number of surface-bound LTCCs suggesting a mechanism by which LTCCs may be involved in modulation of synaptic transmission (Subramanian and Morozov, 2011).

One of the most robust effects of postsynaptic LTCC calcium influx is activation of CREBdependent transcription (Bito et al., 1996; Deisseroth et al., 1998; Dolmetsch et al., 2001; Weick et al., 2003; West et al., 2001). The investigation of CREB-dependent transcriptional 
regulation by the LTCC and cAMP established their role in activation of transient and stable signaling sub-microdomains of mixed and individual type (Kobrinsky et al., 2011). These discrete signaling microdomains might be differentially associated with such specialized processes as spontaneous contractions of muscle cells or the long-term changes underlying synaptic plasticity. While a number of genes are regulated by changes in free calcium generally, and CREB activity specifically, experiments show other levels of regulation. For example, BDNF is preferentially regulated by calcium influx through LTCCs when compared to calcium influx through N-methyl-D-aspartate (NMDA) receptors (Ghosh et al., 1994; Tabuchi et al., 2000). Specifically, calcium influx through LTCCs preferentially activates BDNF promoter I while BDNF promoter III is driven by LTCCs and NMDA receptors equally.

Little is known about the role of $\mathrm{Ca}_{\mathrm{v}} 1.2$ during brain development, however, LTCCs in general are recognized to play a role in the development of ventral hippocampal parvalbumin containing interneurons (Jiang and Swann, 2005), as well as in calcium oscillations that occur in developing Purkinje neurons (Liljelund et al., 2000). It is worth noting that parvalbumin interneurons are reproducibly reported decreased in the brains of individual with schizophrenia (Lisman et al., 2008). Additionally, LTCCs are involved in gamma-aminobutyric acid (GABA) mediated calcium increases in embryonic hypothalamic neurons (Obrietan and van den Pol, 1995). LTCCs also mediate the increased amplitude of $\mathrm{Ca}^{2+}$ transients after activation of GABA-A receptors by muscimol in embryonic hypothalamic neurons after estradiol treatment (Perrot-Sinal et al., 2001), as well as the increased phosphorylation of cyclic AMP response element binding protein found in the hippocampus and hypothalamus of newborn male rats (Perrot-Sinal et al., 2003).

$\mathrm{Ca}_{\mathrm{v}} 1.2$ has been associated with changes in calcium signaling and its effects in aging. For example, phosphorylation of $\mathrm{Ca}_{\mathrm{v}} 1.2$ is increased in the hippocampus of aged rats, possibly accounting for the age-related increase in neuronal Ca2+ influx (Davare and Hell, 2003).

Additionally, $\mathrm{Ca}_{\mathrm{v}} 1.2$ channels have been shown in vitro to interact with amyloid precursor protein (APP), and APP deletion in mice leads to both increased $\mathrm{Ca}_{\mathrm{v}} 1.2$ levels and GABAergic calcium currents in the striatum and hippocampus (Yang et al., 2009). Much work is needed to define how alterations in $\mathrm{Ca}_{\mathrm{v}} 1.2$ levels and function in development and aging may progress into psychiatric dysfunctions.

\section{Function of $\mathrm{Ca}_{\mathrm{v}} 1.2$ in the brain circuits and behaviors of rodents}

The importance of $\mathrm{Ca}_{\mathrm{v}} 1.2$ channels in regulating the functions of brain circuits and behaviors has been shown through administration of LTCC agonists and antagonists, as well as using several genetic knockout approaches. A germline knockout of Cacnalc is embryonically lethal (Seisenberger et al., 2000), however conditional knockout and heterozygous mouse models have been successfully used. LTCCs have been found to play a role in behaviors mediated by the mesolimbic pathway. This pathway traditionally defines the ventral tegmental area (VTA) to nucleus accumbens (NAc) circuit, modulated by interactions with the hippocampus, medial prefrontal cortex, and amygdala (Pierce and Kumaresan, 2006), and is thought to be critical for reward and motivation that can be altered in mood disorders and schizophrenia (Juckel et al., 2003; Nestler and Carlezon, 2006). In rats, administration of the hydrophobic dihydropyridine LTCC antagonist isradipine dosedependently attenuates intake of sweetened drinking water, a rewarding liquid (Calcagnetti and Schechter, 1992), as well as the reinforcing effects of amphetamine (Pucilowski et al., 1995), while nimodipine suppresses the effect of nicotine (Biala, 2003) in conditioned place preference. Additionally, there is evidence that the LTCC antagonist D-cis-diltiazem enhances the rewarding effects of cocaine in the conditioned place preference test when injected in the ventral NAc shell (Chartoff et al., 2006). In mice sensitized to 
psychostimulants, increases in $\mathrm{Ca}_{\mathrm{v}} 1.2$ protein levels in the frontal cortex and limbic forebrain were found (Ford et al., 2009; Shibasaki et al., 2010), as well as increased surface expression of $\mathrm{Ca}_{\mathrm{v}} 1.2$ channels in pyramidal neurons of the medial prefrontal cortex (Ford et al., 2009).

$\mathrm{Ca}_{\mathrm{v}} 1.2$ channels have also been shown to be important during sensitization to stimulants, a behavior mediated in part by VTA to NAc pathway. In rats sensitized to amphetamine, there is an up regulation of the $\mathrm{Ca}_{\mathrm{v}} 1.2$ channel mRNA and protein in dopaminergic neurons in the VTA (Rajadhyaksha, 2004). Repeated micro-injections of LTCC dihydropyridine agonist BayK 8644 in the VTA of rats resulted in an increased behavioral response to cocaine (Licata et al., 2000), and BayK 8644-induced stimulation of LTCCs in the caudate putamen increases extracelluar dopamine levels as measured by microdialysis (Okita et al., 2000). Additionally, it has been shown that peripheral administration of dihydropyridine antagonists attenuates sensitization to stimulants (Biala and Weglinska, 2004; Mills et al., 2007). Some data suggest that $\mathrm{Ca}_{\mathrm{v}} 1.2$ channels are important for the behavioral expression of sensitization, but not the development of sensitization (Giordano et al., 2010; Schierberl et al., 2011).

Dysfunction of the hippocampus has been implicated in the pathogenesis of both mood disorders and schizophrenia, and may be relevant to emotional instability and hippocampal memory dysfunction observed in both disorders (Small et al., 2011). A region specific knockout of Cacnalc in the hippocampus and neocortex of mice leads to a loss of Shaffer collateral/CA1 late-phase long-term potentiation (LTP) (Moosmang et al., 2005). $\mathrm{Ca}_{\mathrm{v}} 1.2$ channels regulate excitability, and have been linked to decreased activation of the MAPK pathway and reduced CREB-dependent transcription, in CA1 pyramidal neurons (Lacinova et al., 2008; Moosmang et al., 2005). Conditional deletion of Cacnalc in the hippocampus and cortex results in hippocampal-dependent behavioral changes, such as impaired spatial memory in the Morris water maze and in a labyrinth maze test (Moosmang et al., 2005; White et al., 2008).

The amygdala plays a central role in regulating fear circuits (Moosmang et al., 2005) and overall limbic system function that is implicated in neuropsychiatric illness (Krishnan and Nestler, 2010). LTCCs are known to modulate amygdala function, as well as behaviors mediated by the amygdala. For example, they have been shown to be important for longterm fear memory formation and LTP in the lateral amygdala (Bauer et al., 2002; Langwieser et al., 2010), as well as for induction of LTP in the basolateral amygdala to dentate gyrus pathway after stimulation (Niikura et al., 2004). Pharmacological inhibitors have demonstrated a role for LTCCs in presynaptic LTP at corticoamygdala synapses (Fourcaudot et al., 2009). In behavioral tests of fear memory, peripheral administration of LTCC blockers interfere with extinction, but not acquisition of fear memory (Cain et al., 2002; Suzuki et al., 2004). Administration of LTCC blockers into the ventricles or directly to the amygdala interferes with acquisition, but not extinction of fear learning (Bauer et al., 2002; Langwieser et al., 2010). Using a conditional knockout mouse model, as well as pharmacological methods, it has been shown that $\mathrm{Ca}_{\mathrm{v}} 1.2$ but not $\mathrm{Ca}_{\mathrm{v}} 1.3$ is the relevant LTCC genetic isoform in the thalamus-amygdala pathway (Langwieser et al., 2010). Genetically modified mice expressing dihydropyridine-insensitive $\mathrm{Ca}_{\mathrm{v}} 1.2\left(\mathrm{Ca}_{\mathrm{v}} 1.2 \mathrm{DHP}-/-\right)$ were resistant to the effects of the dihydropyridine antagonist nifedipine to impair fear extinction, suggesting a crucial role for $\mathrm{Ca}_{\mathrm{v}} 1.2$ channels in fear conditioning (Busquet et al., 2008). Supporting this conclusion, the same group reported that $\mathrm{Ca}_{\mathrm{v}} 1.3$-deficient mice manifested extinction identical to the respective wild type mice (Busquet et al., 2008). Additionally, it has been found that amygdala levels of the $\mathrm{Ca}_{\mathrm{v}} 1.2$ protein is increased in response to fear conditioning in rats (Shinnick-Gallagher et al., 2003). $\mathrm{Ca}_{\mathrm{v}} 1.2$ channels also play a role in observational fear learning, as shown by impaired observational fear learning 
in a mouse model with a selective deletion of $\mathrm{Ca}_{\mathrm{v}} 1.2$ channels in the anterior cingulate cortex (Jeon et al., 2010).

Cacnalc heterozygous knockout mice, expressing decreased $\mathrm{Ca}_{\mathrm{v}} 1.2$ protein levels as well as decreased LTCC current as adults, were protected against depression-like phenotypes (Dao et al., 2010). This finding, although reported in both sexes, was more robust in females. This is consistent with the finding that some SNPs in $C A C N A 1 C$ are associated with a mood disorder diagnosis only in females (Dao et al., 2010). Of potential relevance, the gonadal steroid estrogen has been reported to induce calcium influx via LTCCs in cultured hippocampal neurons in a non-genomic manner (not involving estrogen receptors) (Sarkar et al., 2008). A variety of $\mathrm{Ca}_{\mathrm{v}} 1.2$ antagonists have been shown to reduce despair-like behavior similar to existing antidepressant medications (Cohen et al., 1997; Czyrak et al., 1989, 1990; Mogilnicka et al., 1987; Sinnegger-Brauns et al., 2004). Genetically modified dihydropyridine-insensitive $\mathrm{Ca}_{\mathrm{v}} 1.2 \mathrm{DHP}-/-$ mice were resilient to the antidepressant-like effect of nifedipine in the forced swim test, suggesting that $\mathrm{Ca}_{\mathrm{v}} 1.2$ mediates the antidepressant-like effects of LTCC antagonists (Sinnegger-Brauns et al., 2004).

Moosmang et al. (2005) reported that a conditional forebrain knockout of Cacnalc did not alter anxiety-like or exploratory behavior. However, while Cacnalc heterozygous knockout mice males showed normal performance in anxiety-related procedures, females showed increased anxiety or fewer risk taking behaviors (Dao et al., 2010). In a recent study Lee et al. (2012) showed that mice constitutively heterozygous for Cacnalc manifested anxiety-like behavior in the elevated plus maze test (adult females as well as adolescent males). The authors also generated forebrain specific conditional knockout mice and a prefrontal cortex specific cacna1c knockdown which both also resulted in increased anxiety like behavior (Lee et al., 2012). LTCC antagonists were reported to increase anxiety-like behavior in rats (Viveros et al., 1996), but the effect is apparently species-dependent, as anxiety-like behavior in mice was not affected (Biala and Kruk, 2007). Finally, it has recently been reported that mice expressing a constitutively active G406R mutation of $\mathrm{Ca}_{\mathrm{v}} 1.2 \mathrm{a}_{1 \mathrm{C}}$ subunit, causative of Timothy syndrome in humans, manifested a number of behavioral changes reminiscent of autism including repetitive/perseverative behaviors, altered social interaction and ultrasonic vocalizations, and enhanced tone cued and contextual memory following fear conditioning (Bader et al., 2011).

\section{Effects of CACNA1C on human brain function}

Supporting the rodent data implicating $\mathrm{Ca}_{\mathrm{v}} 1.2$ in basic brain function, a number of recent reports have associated a primary disease-associated SNP in $C A C N A 1 C$, rs 1006737, with variation in human brain function and structure in subjects who have no diagnosable psychiatric illness (Table 2). While polymorphisms in $C A C N A 1 C$ are significantly associated with bipolar disorder, depression, and schizophrenia, such genetic changes only increase probability of disease, and are not deterministic. Thus, a large percentage of the population who do not have disease also carry disease associated SNPs in $C A C N A 1 C$, which allows for studies to dissect the effects of SNPs on brain function and structure. Specifically, multiple reports have associated rs1006737 genotype with differences in performance on a number of neuropsychological tasks in healthy control subjects. Krug et al. (2010) reported that the risk allele was associated with decreased performance on a test of semantic verbal fluency (Krug et al., 2010). The risk allele has also been associated with decreased attention-related performance in alerting and orienting as assessed with a scanneradapted version of the Attention Network Test (Thimm et al., 2011), lower extraversion and higher harm avoidance, trait anxiety, and paranoid ideation scores as assessed via personality questionnaires, and increased startle reactivity (Roussos et al., 2011). Risk allele carriers were also reported to have manifested higher psychopathology scores for 
depression, anxiety, obsessive-compulsive thoughts, interpersonal sensitivity, and neuroticism (Erk et al., 2010). Strohmaier et al. provided an interesting report of sex-specific effect of CACNA1C SNP rs1006737 in a large population based cohort (Strohmaier et al., 2012). In their investigation of personality traits relevant to affective disorders and schizophrenia the authors found that the risk allele of rs1006737 was significantly associated with higher sense of coherence in women. On the other hand, this allele in men was associated with lower sense of coherence, albeit statistically not significant. Overall, Strohmaier et al. observed opposite direction of effect of the genotype of rs 1006737 in males and females for most of the personality traits studied in the cohort. Zhang et al. (2011) reported that the risk allele was associated with impaired working memory in schizophrenia patients and healthy controls, but not bipolar patients. Soeiro-de-Souza et al. (2012) have also recently reported that the risk allele was associated with impairment in facial emotion recognition in bipolar patients, but not in healthy controls.

Consistent with these findings, a large number of functional neuroimaging studies have revealed an association between rs 1006737 genotype and brain activity in healthy controls while undertaking specific tasks. To date these findings include changes in brain activity while performing an attention network task (Thimm et al., 2011), amygdala activity during emotional processing (Jogia et al., 2011; Wessa et al., 2010), bilateral hippocampal activation during episodic memory recall and diminished functional coupling between left and right hippocampal regions (Erk et al., 2010), increased activationof the leftinferior frontalgyrus aswellas the left precuneus during a separate semantic verbal fluency task (Krug et al., 2010), mediotemporal emotional processing and prefronto-cortical working memory processing (Bigos et al., 2010), and reduced corticolimbic/frontotemporal functional connectivity during emotional face-processing (Wang et al., 2011). Radua et al. (2012) found that this same SNP was associated with significant modulation of effective connectivityfrommedial frontalgyrus to left putamensignificantlyreduced during perception of fearfulfaces, but that the effect was primarily in BPD subjects (vs. unaffected relatives and healthy controls).

Three published reports have now indicated that the rs 1006737 risk allele is associated with increased brain gray matter, either total gray matter volume or in specific brain regions in healthy controls (Kempton et al., 2009; Perrier et al., 2011; Wang et al., 2011). Kempton et al. (2009) reported an increase in total gray matter volume. In a larger study with 585 individuals, Franke et al. (2010), specifically attempted to replicate these findings, but could not indicating discordance among reports. It is possible that differences in total gray matter may be reflective of changes in select brain regions, as reported by Perrier et al. (2011) where increases in right amygdala and right hypothalamus were noted. Wang et al. (2011) reported an increase in gray matter volume in select brain regions including bilateral ventral, rostral, and dorsolateral prefrontal cortex, and anterior cingulate and temporal cortices. Perrier et al. (2011) also reported that there was a significant interaction between genotype and a bipolar disorder diagnosis whereby the left putamen was smaller in bipolar patients carrying the risk allele. Additionally, it has been reported that the minor allele for three CACNA1C SNPs (rs2051992, rs2239050, rs7959938) that are all in high LD with each other but distant from rs 1006737 are associated with increased brainstem volume in healthy controls (Franke et al., 2010). In this study there was also an association between rs7959938 and white matter volume in the brainstem, largely overlapping in areas of the midbrain and pons, and also in cerebellum. It is unclear if these effects of CACNA1CSNPs on structural and volumetric outcomes arose during early development, or are only present in adults. However, it is clear that such changes on their own are not pathological as they were identified mostly in psychiatrically normal subjects (Table 2). 


\section{L-type calcium channel antagonists in the treatment of psychiatric disease}

LTCC antagonists are mainly used clinically for treating high blood pressure, angina, and abnormal heart rhythms. Chemically, they are represented by three different structural classes: dihydropyridines, benzothiazepines, and phenylalkylamines, which all act by binding to different sites on $\mathrm{Ca}_{\mathrm{v}} 1.2$ and blocking the calcium current (Triggle, 1992). LTCC antagonists within the same structural class may vary in their affinity for the same calcium channel subtype, as well as for their penetration of the blood-brain barrier. For example, nimodipine and nicardipine, unlike some other dihydropyridines, are considered to have good CNS penetration (Kaplan, 1989). LTCC antagonists have been assessed for the treatment of bipolar disorder and also unipolar depression (see Casamassima et al., 2010a and Levy and Janicak, 2000 for comprehensive reviews). However, studies have yielded mixed results suggesting response in only a subset of patients (most notably rapid cycling where patients transition between mood episodes occurs at a rapid rate) or that these treatments have not yet been optimized (e.g. selectivity for $\mathrm{Ca}_{\mathrm{v}} 1.2$ or blood brain barrier penetrance (Casamassima et al., 2010a; Levy and Janicak, 2000; Mallinger et al., 2008; Pazzaglia et al., 1998)). Many of the early studies were performed with the phenylalkamine verapamil, which has low blood-brain barrier permeability. More recent double-blind placebo studies with dihydropyridines including nimodipine and nicardipine that more efficiently cross blood-brain barrier have suggested that this class of calcium channel medication has efficacy as an adjunctive antidepressant treatment in combination with selective serotonin reuptake inhibitors (SSRIs) or electroconvulsive therapy (Dubovsky et al., 2001; Taragano et al., 2001, 2005). To the best of our knowledge, LTCC antagonists have not been assessed for efficacy in the treatment of schizophrenia. More extensive investigation with LTCC antagonists that readily cross the blood brain barrier are clearly necessary to define the specific profile of this class of medications in bipolar disorder, as well as depression and schizophrenia.

\section{Conclusions}

Underlying genetics are among the strongest risk factors for the development of mood disorders and schizophrenia, and there is shared genetic overlap between DSM-defined disorders including bipolar disorder, unipolar depression, and schizophrenia. This shared genetic overlap is coincident with shared environmental risk factors, as well as extensive overlap in neurobiology-as evidenced by biological markers and endophenotypes-and in efficacious treatments (Demjaha et al., 2011; Gottesman and Gould, 2003; Insel and Cuthbert, 2009). This has contributed to the view that future classification systems for psychiatric illness should be agnostic to current criteria (Cuthbert and Insel, 2010; Insel et al., 2010) and that newtreatments that are basedupon pathophysiology will eventually emerge through a thorough understanding of genetic susceptibility factors (Insel and Scolnick, 2006).

SNPs in CACNA1C are associated with risk of developing diverse DSM-defined disorders including bipolar disorder, depression, and schizophrenia. In addition to being a current statistical "top hit" resultant from bipolar disorder GWA studies, it is also the top finding when combining results of depression or schizophrenia with bipolar disorder sample sets, reinforcing the well established notion that diagnostic categories are not appropriate demarcation points for the effects of genes on behaviors (Gottesman and Gould, 2003; Meyer-Lindenberg and Weinberger, 2006). Available data suggest that CACNA1C belongs to a class of shared susceptibility factors, which cross DSM diagnostic boundaries to influence susceptibility (Table 1). 
We have reviewed these human genetic and clinical findings, as well as the biological functions of $\mathrm{Ca}_{\mathrm{v}} 1.2$ that are likely most relevant to psychiatric disease. While involved in numerous cellular functions, $\mathrm{Ca}_{\mathrm{v}} 1.2$ is strongly implicated in the coupling of cell membrane depolarization to changes in calcium permeability and resultant intracellular signaling pathway activity and ultimately gene transcription and synaptic plasticity. Mouse genetic knockout experiments and studies with LTCC antagonist and agonists indicate that $\mathrm{Ca}_{\mathrm{v}} 1.2$ is involved in proper functioning of many brain regions, including the mesolimbic reward system, hippocampus, and amygdala. Much of the work exploring the effects of LTCC antagonists on activation of signaling pathways and rodent behavior have not been able to distinguish the effects of inhibiting all LTCCs, most notably $\mathrm{Ca}_{\mathrm{v}} 1.2$ and $\mathrm{Ca}_{\mathrm{v}} 1.3$ in the brain, though genetically modified mice expressing dihydropyridine-insensitive $\mathrm{Ca}_{\mathrm{v}} 1.2$ $\left(\mathrm{Ca}_{\mathrm{v}}\right.$ 1.2DHP-/-) have been generated and used to begin to address this critical question (Busquet et al., 2008; Giordano et al., 2010; Sinnegger-Brauns et al., 2004). Existing preclinical and some clinical pharmacological data support inhibiting LTCCs as a possible mechanism of mood stabilization.

Prior to the recent genetic findings, there was a priori evidence suggesting that calcium signaling may play a role in bipolar disorder. Studies of bipolar patients have consistently reported elevated basal and stimulated intracellular calcium levels in peripheral blood cells (Casamassima et al., 2010a; Dubovsky et al., 1989; Emamghoreishi et al., 1997; Perova et al., 2008). However, the relevance of these reports to the current genetic association with $C A C N A 1 C$ is presently unclear. Additional investigation of the role of $\mathrm{Ca}_{\mathrm{v}} 1.2$ in brain function inboth humans and animal models will likely provide novel insights into the pathophysiology of psychiatric disorders and elucidate new approaches for their treatment.

It is evident from the increasing size of cases and controls that are being assessed and the odds ratios reported that the identified polymorphisms in $C A C N A 1 C$ impart only a small contribution to the overall heritability of psychiatric illness (Table 1). However, a number of reports now clearly indicate that genetic variant at SNP rs1006737 is associated with changes in brain structure and function in normal control subjects with a larger effect size (Table 2 and (Rose and Donohoe, 2012)). There is evidence indicating that genetic variation at rs1006737 may be involved in modulating gene expression, with the minor (risk) allele associated with increased expression levels of $C A C N A 1 C$ (Bigos et al., 2010). However, the mechanisms regarding how this gene is regulated by these SNPs or other SNPs in LD is not clear, and the resultant changes in $\mathrm{Ca}_{\mathrm{v}} 1.2$ function and how it is related to disease have not been characterized. The mechanism by which genetic variation in $C A C N A 1 C$ influences risk is likely on the function of particular neuronal circuits, at a level far upstream from the development of disease or presentation of symptoms. Noting that $C A C N A 1 C$ is a susceptibility gene for diverse psychiatric diseases, these changes in circuit function likely converge in a manner that is common across diagnostic categories. It is, however, unclear if this effect of $C A C N A 1 C$ genetic variation is during development, in adults, or perhaps more likely both. A number of additional molecular genetic questions remain to be answered. These include the identification of $C A C N A 1 C$ splice variants associated with particular SNPs, and whether such an association is dependent on brain regions. It also remains critically important to fully address the consequences of changes in splice variation of $C A C N A 1 C$ on neurophysiology and whether these structural changes may lead to an identification of $\mathrm{a}_{1 \mathrm{C}}$ molecular determinant(s) to be used in high-throughput screening for research and development leading to new specific drugs to combat disease (Zuccotti et al., 2011). Defining the answers to these and other critical questions will likely provide important insight into neuropsychiatric disease susceptibility and potentially lead to novel therapeutic targets and approaches. 


\section{Acknowledgments}

This work was supported by a NARSAD "Helen Lowenstein" Young Investigator Award and NIH MH093967 to TDG.

\section{Abbreviations}

\begin{tabular}{|c|c|}
\hline AEI & Allelic expression imbalance \\
\hline ANK3 & Ankyrin 3, node of Ranvier (ankyrin G) \\
\hline APP & Amyloid precursor protein \\
\hline$B D N F$ & Brain derived neurotrophic factor \\
\hline BPD & Bipolar disorder \\
\hline CaBP1 & Calcium binding protein-1 \\
\hline CACNAIC & Voltage dependent $\mathrm{L}$ type calcium channel, alpha $1 \mathrm{C}$ subunit \\
\hline CaM & Calmodulin \\
\hline cAMP & Cyclic adenosine monophosphate \\
\hline CaMK & $\mathrm{Ca} 2+/ \mathrm{CaM}-\mathrm{dependent}$ protein kinases \\
\hline $\mathrm{Ca}_{\mathbf{v}} 1.1$ to 1.4 & $\begin{array}{l}\text { Calcium voltage-dependent channel, } 1.1 \text { to } 1.4 \text { representing the voltage } \\
\text { of activation of the respective channel }\end{array}$ \\
\hline cDNA & Complementary DNA \\
\hline CICR & Calcium-induced intracellular calcium release \\
\hline CREB & cAMP response element binding protein \\
\hline DHP & Dihydropyridine \\
\hline DSM IV & Diagnostic and Statistical Manual IV \\
\hline Erk & Extracellular signal-regulated kinases \\
\hline GABA & Gamma-aminobutyric acid \\
\hline GenRED & Genetics of Recurrent Early-onset Major Depression consortium \\
\hline GWAS & Genome-wide association study \\
\hline LD & Linkage disequilibrium \\
\hline LTCC & L-type calcium channel \\
\hline LTP & long-term potentiation \\
\hline MAOI & Monoamine oxidase inhibitor \\
\hline MAPK & Mitogen-activated protein kinase \\
\hline MDD & Major depressive disorder \\
\hline MIR137 & microRNA 137 \\
\hline NAc & Nucleus accumbens \\
\hline NIMH-GIBD & $\begin{array}{l}\text { National Institute of Mental Health-Genetics Initiative Bipolar Disorder } \\
\text { consortium }\end{array}$ \\
\hline NMDA & N-methyl-D-aspartate \\
\hline ODZ4 & odd Oz/ten-m homolog 4 (Drosophila) \\
\hline
\end{tabular}




$\begin{array}{ll}\text { OR } & \text { Odds ratio } \\ \text { PCR } & \text { Polymerase chain reaction } \\ \text { PGC } & \text { Psychiatric Genetics Consortium } \\ \text { RyR } & \text { Ryanodine receptors } \\ \text { SNP } & \text { Single nucleotide polymorphism } \\ \text { SSRI } & \text { Selective serotonin reuptake inhibitor } \\ \text { SZ } & \text { Schizophrenia } \\ \text { STAR*D study } & \text { Sequenced treatment alternatives to relieve depression study } \\ \text { TCA } & \text { Tricyclic antidepressant } \\ \text { VTA } & \text { Ventral tegmental area } \\ \text { WTCCC } & \text { Wellcome Trust Case-Control Consortium } \\ \text { ZNF804A } & \text { zinc finger protein 804A }\end{array}$

\section{References}

Abernethy DR, Soldatov NM. Structure-functional diversity of human L-type $\mathrm{Ca}^{2+}$ channel: perspectives for new pharmacological targets. Journal of Pharmacology and Experimental Therapeutics. 2002; 300:724-728. [PubMed: 11861774]

Abiria SA, Colbran RJ. CaMKII associates with $\mathrm{Ca}_{\mathrm{V}} 1.2$ L-type calcium channels via selected $\beta$ subunits to enhance regulatory phosphorylation. Journal of Neurochemistry. 2010; 112:150-161. [PubMed: 19840220]

Bader PL, Faizi M, Kim LH, Owen SF, Tadross MR, Alfa RW, Bett GC, Tsien RW, Rasmusson RL, Shamloo M. Mouse model of Timothy syndrome recapitulates triad of autistic traits. Proceedings of the National Academy of Sciences USA. 2011; 108:15432-15437.

Barad M. Later developments: molecular keys to age-related memory impairment. Alzheimer Disease \& Associated Disorders. 2003; 17:168-176. [PubMed: 14512831]

Barrett CF, Tsien RW. The Timothy syndrome mutation differentially affects voltage- and calciumdependent inactivation of $\mathrm{Ca}_{\mathrm{V}} 1.2$ L-type calcium channels. Proceedings of the National Academy of Sciences USA. 2008; 105:2157-2162.

Bauer EP, Schafe GE, LeDoux JE. NMDA receptors and L-type voltage-gated calcium channels contribute to long-term potentiation and different components of fear memory formation in the lateral amygdala. Journal of Neuroscience. 2002; 22:5239-5249. [PubMed: 12077219]

Berrettini W. Evidence for shared susceptibility in bipolar disorder and schizophrenia. American Journal of Medical Genetics Part C, Seminars in Medical Genetics. 2003; 123C:59-64.

Biala G. Calcium channel antagonists suppress nicotine-induced place preference and locomotor sensitization in rodents. Polish Journal of Pharmacology. 2003; 55:327-335. [PubMed: 14506311]

Biala G, Kruk M. Amphetamine-induced anxiety-related behavior in animal models. Pharmacological Reports. 2007; 59:636-644. [PubMed: 18195452]

Biala G, Weglinska B. Calcium channel antagonists attenuate cross-sensitization to the rewarding and/ or locomotor effects of nicotine, morphine and MK-801. Journal of Pharmacy and Pharmacology. 2004; 56:1021-1028. [PubMed: 15285847]

Bigos KL, Mattay VS, Callicott JH, Straub RE, Vakkalanka R, Kolachana B, Hyde TM, Lipska BK, Kleinman JE, Weinberger DR. Genetic variation in CACNA1C affects brain circuitries related to mental illness. Archives of General Psychiatry. 2010; 67:939-945. [PubMed: 20819988]

Bito H, Deisseroth K, Tsien RW. CREB phosphorylation and dephosphory-lation: $\mathrm{Ca}^{2+}$ - and stimulus duration-dependent switch for hippocampal gene expression. Cell. 1996; 87:1203-1214. [PubMed: 8980227] 
Brillantes AMB, Bezprozvannaya S, Marks AR. Developmental and tissue-specific regulation of rabbit skeletal and cardiac muscle calcium channels involved in excitation-contraction coupling. Circulation Research. 1994; 75:503-510. [PubMed: 8062423]

Burton PR, Clayton DG, Cardon LR, Craddock N, Deloukas P, Duncanson A, Kwiatkowski DP, McCarthy MI, Ouwehand WH, Samani NJ, Todd JA, Donnelly P, Barrett JC, Burton PR, Davison D, Donnelly P, Easton D, Evans D, Leung HT, Marchini JL, Morris AP, Spencer CC, Tobin MD, Cardon LR, Clayton DG, Attwood AP, Boorman JP, Cant B, Everson U, Hussey JM, Jolley JD, Knight AS, Koch K, Meech E, Nutland S, Prowse CV, Stevens HE, Taylor NC, Walters GR, Walker NM, Watkins NA, Winzer T, Todd JA, Ouwehand WH, Jones RW, McArdle WL, Ring SM, Strachan DP, Pembrey M, Breen G, St Clair D, Caesar S, Gordon-Smith K, Jones L, Fraser C, Green EK, Grozeva D, Hamshere ML, Holmans PA, Jones IR, Kirov G, Moskvina V, Nikolov I, O'Donovan MC, Owen MJ, Craddock N, Collier DA, Elkin A, Farmer A, Williamson R, McGuffin P, Young AH, Ferrier IN, Ball SG, Balmforth AJ, Barrett JH, Bishop DT, Iles MM, Maqbool A, Yuldasheva N, Hall AS, Braund PS, Burton PR, Dixon RJ, Mangino M, Suzanne S, Tobin MD, Thompson JR, Samani NJ, Bredin F, Tremelling M, Parkes M, Drummond H, Lees CW, Nimmo ER, Satsangi J, Fisher SA, Forbes A, Lewis CM, Onnie CM, Prescott NJ, Sanderson J, Mathew CG, Barbour J, Mohiuddin MK, Todhunter CE, Mansfield JC, Ahmad T, Cummings FR, Jewell DP, Webster J, Brown MJ, Clayton DG, Lathrop GM, Connell J, Dominczak A, Samani NJ, Marcano CA, Burke B, Dobson R, Gungadoo J, Lee KL, Munroe PB, Newhouse SJ, Onipinla A, Wallace C, Xue M, Caulfield M, Farrall M, Barton A, Bruce IN, Donovan H, Eyre S, Gilbert PD, Hider SL, Hinks AM, John SL, Potter C, Silman AJ, Symmmons DP, Thomson W, Worthington J, Clayton DG, Dunger DB, Nutland S, Stevens HE, Walker NM, Widmer B, Todd JA, Frayling TA, Freathy RM, Lango H, Perry JR, Shields BM, Weedon MN, Hattersley AT, Hitman GA, Walker M, Elliott KS, Groves CJ, Lindgren CM, Rayner NW, Timpson NJ, Zeggini E, McCarthy MI, Newport M, Sirugo G, Lyons E, Vanberg F, Hill AV, Bradbury LA, Farrar C, Pointon JJ, Wordsworth P, Brown MA, Franklyn JA, Heward JM, Simmonds MJ, Gough SC, Seal S, Stratton MR, Rahman N, Ban M, Goris A, Sawcer SJ, Compston A, Conway D, Jallow M, Newport M, Sirugo G, Rockett KA, Kwiatowski DP, Bumpstead SJ, Chaney A, Downes K, Ghori MJ, Gwilliam R, Hunt SE, Inouye M, Keniry A, King E, McGinnis R, Potter S, Ravindrarajah R, Whittaker P, Widden C, Withers D, Deloukas P, Leung HT, Nutland S, Stevens HE, Walker NM, Todd JA, Easton D, Clayton DG, Burton PR, Tobin MD, Barrett JC, Evans D, Morris AP, Cardon LR, Cardin NJ, Davison D, Ferreira T, Pereira-Gale J, Hallgrimsdottir IB, Howie BN, Marchini JL, Spencer CC, Su Z, Teo YY, Vukcevic D, Donnelly P, Bentley D, Brown MA, Gordon LR, Caulfield M, Clayton DG, Compston A, Craddock N, Deloukas P, Donnelly P, Farrall M, Gough SC, Hall AS, Hattersley AT, Hill AV, Kwiatkowski DP, Mathew C, McCarthy MI, Ouwehand WH, Parkes M, Pembrey M, Rahman N, Samani NJ, Stratton MR, Todd JA, Worthington J. Genome-wide association study of 14,000 cases of seven common diseases and 3,000 shared controls. Nature. 2007; 447:661-678. [PubMed: 17554300]

Busquet P, Hetzenauer A, Sinnegger-Brauns MJ, Striessnig J, Singewald N. Role of L-type $\mathrm{Ca}^{2+}$ channel isoforms in the extinction of conditioned fear. Learning \& Memory. 2008; 15:378-386. [PubMed: 18441296]

Cain CK, Blouin AM, Barad M. L-type voltage-gated calcium channels are required for extinction, but not for acquisition or expression, of conditional fear in mice. Journal of Neuroscience. 2002; 22:9113-9121. [PubMed: 12388619]

Calcagnetti DJ, Schechter MD. Attenuation of drinking sweetened water following calcium channel blockade. Brain Research Bulletin. 1992; 28:967-973. [PubMed: 1386279]

Cannon TD, Kaprio J, Lonnqvist J, Huttunen M, Koskenvuo M. The genetic epidemiology of schizophrenia in a Finnish twin cohort. A population-based modeling study. Archives of General Psychiatry. 1998; 55:67-74. [PubMed: 9435762]

Cardno AG, Gottesman II. Twin studies of schizophrenia: from bow-and-arrow concordances to star wars Mx and functional genomics. American Journal of Medical Genetics. 2000; 97:12-17. [PubMed: 10813800]

Casamassima F, Hay AC, Benedetti A, Lattanzi L, Cassano GB, Perlis RH. L-type calcium channels and psychiatric disorders: a brief review. American Journal of Medical Genetics Part B: Neuropsychiatric Genetics. 2010a; 153B:1373-1390. 
Casamassima F, Huang J, Fava M, Sachs GS, Smoller JW, Cassano GB, Lattanzi L, Fagerness J, Stange JP, Perlis RH. Phenotypic effects of a bipolar liability gene among individuals with major depressive disorder. American Journal of Medical Genetics Part B: Neuropsychiatric Genetics. 2010b; 153B:303-309.

Catterall WA. Voltage-gated calcium channels. Cold Spring Harbor Perspectives in Biology. 2011; $3: 1-23$.

Chartoff EH, Pliakas AM, Carlezon WA Jr. Microinjection of the L-type calcium channel antagonist diltiazem into the ventral nucleus accumbens shell facilitates cocaine-induced conditioned place preferences. Biological Psychiatry. 2006; 59:1236-1239. [PubMed: 16458265]

Chubb JE, Bradshaw NJ, Soares DC, Porteous DJ, Millar JK. The DISC locus in psychiatric illness. Molecular Psychiatry. 2008; 13:36-64. [PubMed: 17912248]

Cohen C, Perrault G, Sanger DJ. Assessment of the antidepressant-like effects of L-type voltagedependent channel modulators. Behavioural Pharmacology. 1997; 8:629-638. [PubMed: 9832975]

Cuthbert BN, Insel TR. Toward new approaches to psychotic disorders: the NIMH Research Domain Criteria project. Schizophrenia Bulletin. 2010; 36:1061-1062. [PubMed: 20929969]

Czyrak A, Mogilnicka E, Maj J. Dihydropyridine calcium channel antagonists as antidepressant drugs in mice and rats. Neuropharmacology. 1989; 28:229-233. [PubMed: 2725849]

Czyrak A, Mogilnicka E, Siwanowicz J, Maj J. Some behavioral effects of repeated administration of calcium channel antagonists. Pharmacology Biochemistry \& Behavior. 1990; 35:557-560.

Dai B, Saada N, Echetebu C, Dettbarn C, Palade P. A new promoter for $a_{1 C}$ subunit of human L-type cardiac calcium channel $\mathrm{Ca}_{\mathrm{v}}$ 1.2. Biochemical and Biophysical Research Communications. 2002; 296:429-433. [PubMed: 12163037]

Dao DT, Mahon PB, Cai X, Kovacsics CE, Blackwell RA, Arad M, Shi J, Zandi PP, O’Donnell P, Knowles JA, Weissman MM, Coryell W, Scheftner WA, Lawson WB, Levinson DF, Thompson SM, Potash JB, Gould TD. Mood disorder susceptibility gene CACNA1C modifies mood-related behaviors in mice and interacts with sex to influence behavior in mice and diagnosis in humans. Biological Psychiatry. 2010; 68:801-810. [PubMed: 20723887]

Davare MA, Hell JW. Increased phosphorylation of the neuronal L-type $\mathrm{Ca}^{2+}$ channel $\mathrm{Ca}_{\mathrm{v}} 1.2$ during aging. Proceedings of the National Academy of Sciences USA. 2003; 100:16018-16023.

Deisseroth K, Heist EK, Tsien RW. Translocation of calmodulin to the nucleus supports CREB phosphorylation in hippocampal neurons. Nature. 1998; 392:198-202. [PubMed: 9515967]

Demjaha A, Maccabe JH, Murray RM. How genes and environmental factors determine the different neurodevelopmental trajectories of schizophrenia and bipolar disorder. Schizophrenia Bulletin. 2011; 38:209-214. [PubMed: 21857009]

Depil K, Beyl S, Stary-Weinzinger A, Hohaus A, Timin E, Hering S. Timothy mutation disrupts the link between activation and inactivation in $\mathrm{Ca}_{\mathrm{V}} 1.2$ protein. Journal of Biological Chemistry. 2011; 286:31557-31564. [PubMed: 21685391]

Dolmetsch RE, Pajvani U, Fife K, Spotts JM, Greenberg ME. Signaling to the nucleus by an L-type calcium channel-calmodulin complex through the MAP kinase pathway. Science. 2001; 294:333339. [PubMed: 11598293]

Dolphin AC. Calcium channel diversity: multiple roles of calcium channel subunits. Current Opinion in Neurobiology. 2009; 19:237-244. [PubMed: 19559597]

Dubovsky SL, Buzan R, Thomas M, Kassner C, Cullum CM. Nicardipine improves the antidepressant action of ECT but does not improve cognition. Journal of ECT. 2001; 17:3-10. [PubMed: 11281512]

Dubovsky SL, Christiano J, Daniell LC, Franks RD, Murphy J, Adler L, Baker N, Harris RA. Increased platelet intracellular calcium concentration in patients with bipolar affective disorders. Archives of General Psychiatry. 1989; 46:632-638. [PubMed: 2735813]

Dudkin SM, Polev PV, Soldatov NM. Calcium entry blockers and oxiracetam have opposite effects on the density of dihydropyridine receptors in rat cerebral cortex. Brain Research. 1990; 525:319321. [PubMed: 2174714]

Emamghoreishi M, Schlichter L, Li PP, Parikh S, Sen J, Kamble A, Warsh JJ. High intracellular calcium concentrations in transformed lymphoblasts from subjects with bipolar I disorder. American Journal of Psychiatry. 1997; 154:976-982. [PubMed: 9210749] 
Erk S, Meyer-Lindenberg A, Schnell K, Opitz von Boberfeld C, Esslinger C, Kirsch P, Grimm O, Arnold C, Haddad L, Witt SH, Cichon S, Nothen MM, Rietschel M, Walter H. Brain function in carriers of a genome-wide supported bipolar disorder variant. Archives of General Psychiatry. 2010; 67:803-811. [PubMed: 20679588]

Feron O, Octave JN, Christen MO, Godfraind T. Quantification of two splicing events in the L-type calcium channel $a_{1}$ subunit of intestinal smooth muscle and other tissues. European Journal of Biochemistry. 1994; 222:195-202. [PubMed: 8200343]

Ferreira MA, O’Donovan MC, Meng YA, Jones IR, Ruderfer DM, Jones L, Fan J, Kirov G, Perlis RH, Green EK, Smoller JW, Grozeva D, Stone J, Nikolov I, Chambert K, Hamshere ML, Nimgaonkar VL, Moskvina V, Thase ME, Caesar S, Sachs GS, Franklin J, Gordon-Smith K, Ardlie KG, Gabriel SB, Fraser C, Blumenstiel B, Defelice M, Breen G, Gill M, Morris DW, Elkin A, Muir WJ, McGhee KA, Williamson R, MacIntyre DJ, MacLean AW, St CD, Robinson M, Van Beck M, Pereira AC, Kandaswamy R, McQuillin A, Collier DA, Bass NJ, Young AH, Lawrence J, Ferrier IN, Anjorin A, Farmer A, Curtis D, Scolnick EM, McGuffin P, Daly MJ, Corvin AP, Holmans PA, Blackwood DH, Gurling HM, Owen MJ, Purcell SM, Sklar P, Craddock N. Collaborative genomewide association analysis supports a role for ANK3 and CACNA1C in bipolar disorder. Nature Genetics. 2008; 40:1056-1058. [PubMed: 18711365]

Ford KA, Wolf ME, Hu XT. Plasticity of L-type $\mathrm{Ca}^{2+}$ channels after cocaine withdrawal. Synapse. 2009; 63:690-697. [PubMed: 19360908]

Fourcaudot E, Gambino F, Casassus G, Poulain B, Humeau Y, Luthi A. L-type voltage-dependent $\mathrm{Ca}^{2+}$ channels mediate expression of presynaptic LTP in amygdala. Nature Neuroscience. 2009; 12:1093-1095.

Franke B, Vasquez AA, Veltman JA, Brunner HG, Rijpkema M, Fernandez G. Genetic variation in CACNA1C, a gene associated with bipolar disorder, influences brainstem rather than gray matter volume in healthy individuals. Biological Psychiatry. 2010; 68:586-588. [PubMed: 20638048]

Ghosh A, Carnahan J, Greenberg ME. Requirement for BDNF in activity-dependent survival of cortical neurons. Science. 1994; 263:1618-1623. [PubMed: 7907431]

Giordano TP, Tropea TF, Satpute SS, Sinnegger-Brauns MJ, Striessnig J, Kosofsky BE, Rajadhyaksha AM. Molecular switch from L-type $\mathrm{Ca}_{\mathrm{V}} 1.3$ to $\mathrm{Ca}_{\mathrm{V}} 1.2 \mathrm{Ca}^{2+}$ channel signaling underlies long-term psychostimulant-induced behavioral and molecular plasticity. Journal of Neuroscience. 2010; 30:17051-17062. [PubMed: 21159975]

Gottesman II, Laursen TM, Bertelsen A, Mortensen PB. Severe mental disorders in offspring with 2 psychiatrically ill parents. Archives of General Psychiatry. 2010; 67:252-257. [PubMed: 20194825]

Gottesman II, Gould TD. The endophenotype concept in psychiatry: etymology and strategic intentions. American Journal of Psychiatry. 2003; 160:636-645. [PubMed: 12668349]

Green EK, Grozeva D, Jones I, Jones L, Kirov G, Caesar S, Gordon-Smith K, Fraser C, Forty L, Russell E, Hamshere ML, Moskvina V, Nikolov I, Farmer A, McGuffin P, Holmans PA, Owen MJ, O'Donovan MC, Craddock N. The bipolar disorder risk allele at CACNA1C also confers risk of recurrent major depression and of schizophrenia. Molecular Psychiatry. 2010; 15:1016-1022. [PubMed: 19621016]

Halling DB, Aracena-Parks P, Hamilton SL. Regulation of voltage-gated $\mathrm{Ca}^{2+}$ channels by calmodulin. Science STKE. 2005:re15.

Hamshere ML, Walters JT, Smith R, Richards AL, Green E, Grozeva D, Jones I, Forty L, Jones L, Gordon-Smith K, Riley B, O’Neill T, Kendler KS, Sklar P, Purcell S, Kranz J, Morris D, Gill M, Holmans P, Craddock N, Corvin A, Owen MJ, O’Donovan MC. Genome-wide significant associations in schizophrenia to ITIH3/4 CACNA1C and SDCCAG8, and extensive replication of associations reported by the Schizophrenia PGC. Molecular Psychiatry. 2012

Hill WG. Estimation of linkage disequilibrium in randomly mating populations. Heredity (Edinb). 1974; 33:229-239. [PubMed: 4531429]

Hofmann F, Biel M, Flockerzi V. Molecular basis for $\mathrm{Ca}^{2+}$ channel diversity. Annual Review of Neuroscience. 1994; 17:399-418.

Hudmon A, Schulman H, Kim J, Maltez JM, Tsien RW, Pitt GS. CaMKII tethers to L-type Ca ${ }^{2+}$ channels, establishing a local and dedicated integrator of $\mathrm{Ca}^{2+}$ signals for facilitation. Journal of Cell Biology. 2005; 171:537-547. [PubMed: 16275756] 
Insel T, Cuthbert B, Garvey M, Heinssen R, Pine DS, Quinn K, Sanislow C, Wang P. Research domain criteria (RDoC): toward a new classification framework for research on mental disorders. American Journal of Psychiatry. 2010; 167:748-751. [PubMed: 20595427]

Insel TR, Cuthbert BN. Endophenotypes: bridging genomic complexity and disorder heterogeneity. Biological Psychiatry. 2009; 66:988-989. [PubMed: 19900610]

Insel TR, Scolnick EM. Cure therapeutics and strategic prevention: raising the bar for mental health research. Molecular Psychiatry. 2006; 11:11-17. [PubMed: 16355250]

Jeon D, Kim S, Chetana M, Jo D, Ruley HE, Lin SY, Rabah D, Kinet JP, Shin HS. Observational fear learning involves affective pain system and $\mathrm{Ca}_{\mathrm{V}} 1.2 \mathrm{Ca}^{2+}$ channels in ACC. Nature Neuroscience. 2010; 13:482-488.

Jiang M, Swann JW. A role for L-type calcium channels in the maturation of parvalbumin-containing hippocampal interneurons. Neuroscience. 2005; 135:839-850. [PubMed: 16154277]

Jogia J, Ruberto G, Lelli-Chiesa G, Vassos E, Maierú M, Tatarelli R, Girardi P, Collier D, Frangou S. The impact of the CACNA1C gene polymorphism on frontolimbic function in bipolar disorder. Molecular Psychiatry. 2011

Johnson AD, Zhang Y, Papp AC, Pinsonneault JK, Lim JE, Saffen D, Dai Z, Wang D, Sadee W. Polymorphisms affecting gene transcription and mRNA processing in pharmacogenetic candidate genes: detection through allelic expression imbalance in human target tissues. Pharmacogenetics Genomics. 2008; 18:781-791.

Juckel G, Sass L, Heinz A. Anhedonia, self-experience in schizophrenia, and implications for treatment. Pharmacopsychiatry. 2003; 36 (Suppl 3):S176-S180. [PubMed: 14677076]

Kaplan NM. Calcium entry blockers in the treatment of hypertension. Current status and future prospects. Journal of the American Medical Association. 1989; 262:817-823. [PubMed: 2664242]

Keers R, Farmer AE, Aitchison KJ. Extracting a needle from a haystack: reanalysis of whole genome data reveals a readily translatable finding. Psychological Medicine. 2009; 39:1231-1235. [PubMed: 19215628]

Kempton MJ, Ruberto G, Vassos E, Tatarelli R, Girardi P, Collier D, Frangou S. Effects of the CACNA1C risk allele for bipolar disorder on cerebral gray matter volume in healthy individuals. American Journal of Psychiatry. 2009; 166:1413-1414. [PubMed: 19952088]

Kendler KS, Prescott CA. A population-based twin study of lifetime major depression in men and women. Archives of General Psychiatry. 1999; 56:39-44. [PubMed: 9892254]

Kieseppä T, Partonen T, Haukka J, Kaprio J, Lönnqvist J. High concordance of bipolar I disorder in a nationwide sample of twins. American Journal of Psychiatry. 2004; 161:1814-1821. [PubMed: 15465978]

Kim S, Yun HM, Baik JH, Chung KC, Nah SY, Rhim H. Functional interaction of neuronal $\mathrm{Ca}_{\mathrm{v}} 1.3 \mathrm{~L}$ type calcium channel with ryanodine receptor type 2 in the rat hippocampus. Journal of Biological Chemistry. 2007; 282:32877-32889. [PubMed: 17823125]

Kobrinsky E, Duong SQ, Sheydina A, Soldatov NM. Microdomain organization and frequencydependence of CREB-dependent transcriptional signaling in heart cells. The FASEB Journal. 2011; 25:1544-1555.

Kolarow R, Brigadski T, Lessmann V. Postsynaptic secretion of BDNF and NT-3 from hippocampal neurons depends on calcium calmodulin kinase II signaling and proceeds via delayed fusion pore opening. Journal of Neuroscience. 2007; 27:10350-10364. [PubMed: 17898207]

Krishnan V, Nestler EJ. Linking molecules to mood: new insight into the biology of depression. American Journal of Psychiatry. 2010; 167:1305-1320. [PubMed: 20843874]

Krug A, Nieratschker V, Markov V, Krach S, Jansen A, Zerres K, Eggermann T, Stocker T, Shah NJ, Treutlein J, Muhleisen TW, Kircher T. Effect of CACNA1C rs1006737 on neural correlates of verbal fluency in healthy individuals. Neuroimage. 2010; 49:1831-1836. [PubMed: 19781653]

Lacinova L, Moosmang S, Langwieser N, Hofmann F, Kleppisch T. Cav1.2 calcium channels modulate the spiking pattern of hippocampal pyramidal cells. Life Science. 2008; 82:41-49.

Langwieser N, Christel CJ, Kleppisch T, Hofmann F, Wotjak CT, Moosmang S. Homeostatic switch in hebbian plasticity and fear learning after sustained loss of Cav1.2 calcium channels. Journal of Neuroscience. 2010; 30:8367-8375. [PubMed: 20573883] 
Lao QZ, Kobrinsky E, Liu Z, Soldatov NM. Oligomerization of $\mathrm{Ca}_{\mathrm{v}} \beta$ subunits is an essential correlate of $\mathrm{Ca}^{2+}$ channel activity. The FASEB Journal. 2010; 24:5024-5032.

Lee AS, Ra S, Rajadhyaksha AM, Britt JK, De Jesus-Cortes H, Gonzales KL, Lee A, Moosmang S, Hofmann F, Pieper AA, Rajadhyaksha AM. Forebrain elimination of cacnalc mediates anxietylike behavior in mice. Molecular Psychiatry. 2012 [Epub ahead of print].

Leitch B, Szostek A, Lin R, Shevtsova O. Subcellular distribution of L-type calcium channel subtypes in rat hippocampal neurons. Neuroscience. 2009; 164:641-657. [PubMed: 19665524]

Lett TA, Zai CC, Tiwari AK, Shaikh SA, Likhodi O, Kennedy JL, Muller DJ. ANK3, CACNA1C and ZNF804A gene variants in bipolar disorders and psychosis subphenotype. World Journal of Biological Psychiatry. 2011; 12:392-397. [PubMed: 21767209]

Levy NA, Janicak PG. Calcium channel antagonists for the treatment of bipolar disorder. Bipolar Disorders. 2000; 2:108-119. [PubMed: 11252650]

Lewontin RC. The interaction of selection and linkage I. General considerations; heterotic models. Genetics. 1964; 49:49-67. [PubMed: 17248194]

Lewontin RC. On measures of gametic disequilibrium. Genetics. 1988; 120:849-852. [PubMed: 3224810]

Liao P, Yu D, Li G, Yong TF, Soon JL, Chua YL, Soong TW. A smooth muscle Ca 1.2 calcium channel splice variant underlies hyperpolarized window current and enhanced state-dependent inhibition by nifedipine. Journal of Biological Chemistry. 2007; 282:35133-35142. [PubMed: 17916557]

Licata SC, Freeman AY, Pierce-Bancroft AF, Pierce RC. Repeated stimulation of L-type calcium channels in the rat ventral tegmental area mimics the initiation of behavioral sensitization to cocaine. Psychopharmacology (Berl). 2000; 152:110-118. [PubMed: 11041323]

Lichtenstein P, Yip BH, Bjork C, Pawitan Y, Cannon TD, Sullivan PF, Hultman CM. Common genetic determinants of schizophrenia and bipolar disorder in Swedish families: a populationbased study. Lancet. 2009; 373:234-239. [PubMed: 19150704]

Liljelund P, Netzeband JG, Gruol DL. L-Type calcium channels mediate calcium oscillations in early postnatal Purkinje neurons. Journal of Neuroscience. 2000; 20:7394-7403. [PubMed: 11007898]

Lisman JE, Coyle JT, Green RW, Javitt DC, Benes FM, Heckers S, Grace AA. Circuit-based framework for understanding neurotransmitter and risk gene interactions in schizophrenia. Trends on Neurosciences. 2008; 31:234-242.

Liu Y, Blackwood DH, Caesar S, de Geus EJ, Farmer A, Ferreira MA, Ferrier IN, Fraser C, GordonSmith K, Green EK, Grozeva D, Gurling HM, Hamshere ML, Heutink P, Holmans PA, Hoogendijk WJ, Hottenga JJ, Jones L, Jones IR, Kirov G, Lin D, McGuffin P, Moskvina V, Nolen WA, Perlis RH, Posthuma D, Scolnick EM, Smit AB, Smit JH, Smoller JW, St Clair D, van Dyck R, Verhage M, Willemsen G, Young AH, Zandbelt T, Boomsma DI, Craddock N, O'Donovan MC, Owen MJ, Penninx BW, Purcell S, Sklar P, Sullivan PF. Meta-analysis of genome-wide association data of bipolar disorder and major depressive disorder. Molecular Psychiatry. 2011; 16:2-4. [PubMed: 20351715]

Maier W. Common risk genes for affective and schizophrenic psychoses. European Archives of Psychiatry and Clinical Neuroscience. 2008; 258 (Suppl 2):37-40. [PubMed: 18516516]

Mallinger AG, Thase ME, Haskett R, Buttenfield J, Luckenbaugh DA, Frank E, Kupfer DJ, Manji HK. Verapamil augmentation of lithium treatment improves outcome in mania unresponsive to lithium alone: preliminary findings and a discussion of therapeutic mechanisms. Bipolar Disorder. 2008; 10:856-866.

McGuffin P, Katz R, Watkins S, Rutherford J. A hospital-based twin register of the heritability of DSM-IV unipolar depression. Archives of General Psychiatry. 1996; 53:129-136. [PubMed: 8629888]

McGuffin P, Rijsdijk F, Andrew M, Sham P, Katz R, Cardno A. The heritability of bipolar affective disorder and the genetic relationship to unipolar depression. Archives of General Psychiatry. 2003; 60:497-502. [PubMed: 12742871]

Meyer-Lindenberg A, Weinberger DR. Intermediate phenotypes and genetic mechanisms of psychiatric disorders. Nature Reviews Neuroscience. 2006; 7:818-827. 
Mikami A, Imoto K, Tanabe T, Niidome T, Mori Y, Takeshima H, Narumiya S, Numa S. Primary structure and functional expression of the cardiac dihydropyridine-sensitive calcium channel. Nature. 1989; 340:230-233. [PubMed: 2474130]

Mills K, Ansah TA, Ali SF, Mukherjee S, Shockley DC. Augmented behavioral response and enhanced synaptosomal calcium transport induced by repeated cocaine administration are decreased by calcium channel blockers. Life Science. 2007; 81:600-608.

Mogilnicka E, Czyrak A, Maj J. Dihydropyridine calcium channel antagonists reduce immobility in the mouse behavioral despair test; antidepressants facilitate nifedipine action. European Journal of Pharmacology. 1987; 138:413-416. [PubMed: 3622617]

Moosmang S, Haider N, Klugbauer N, Adelsberger H, Langwieser N, Muller J, Stiess M, Marais E, Schulla V, Lacinova L, Goebbels S, Nave KA, Storm DR, Hofmann F, Kleppisch T. Role of hippocampal $\mathrm{Ca}_{\mathrm{V}} 1.2 \mathrm{Ca}^{2+}$ channels in NMDA receptor-independent synaptic plasticity and spatial memory. Journal of Neuroscience. 2005; 25:9883-9892. [PubMed: 16251435]

Moskvina V, Craddock N, Holmans P, Nikolov I, Pahwa JS, Green E, Owen MJ, O’Donovan MC. Gene-wide analyses of genome-wide association data sets: evidence for multiple common risk alleles for schizophrenia and bipolar disorder and for overlap in genetic risk. Molecular Psychiatry. 2009; 14:252-260. [PubMed: 19065143]

Narayanan D, Xi Q, Pfeffer LM, Jaggar JH. Mitochondria control functional CaV1.2 expression in smooth muscle cells of cerebral arteries. Circulation Research. 2010; 107:631-641. [PubMed: 20616314]

Nestler EJ, Carlezon WA Jr. The mesolimbic dopamine reward circuit in depression. Biological Psychiatry. 2006; 59:1151-1159. [PubMed: 16566899]

Niikura Y, Abe K, Misawa M. Involvement of L-type $\mathrm{Ca}^{2+}$ channels in the induction of long-term potentiation in the basolateral amygdala-dentate gyrus pathway of anesthetized rats. Brain Research. 2004; 1017:218-221. [PubMed: 15261117]

Nyegaard M, Demontis D, Foldager L, Hedemand A, Flint TJ, Sorensen KM, Andersen PS, Nordentoft M, Werge T, Pedersen CB, Hougaard DM, Mortensen PB, Mors O, Borglum AD. CACNA1C (rs1006737) is associated with schizophrenia. Molecular Psychiatry. 2010; 15:119121. [PubMed: 20098439]

Obermair GJ, Szabo Z, Bourinet E, Flucher BE. Differential targeting of the L-type $\mathrm{Ca}^{2+}$ channel $\mathrm{a}_{1 \mathrm{C}}$ (CaV1.2) to synaptic and extrasynaptic compartments in hippocampal neurons. European Journal of Neuroscience. 2004; 19:2109-2122. [PubMed: 15090038]

Obrietan K, van den Pol AN. GABA neurotransmission in the hypothalamus: developmental reversal from $\mathrm{Ca}^{2+}$ elevating to depressing. Journal of Neuroscience. 1995; 15:5065-5077. [PubMed: 7623135]

Okita M, Watanabe Y, Taya K, Utsumi H, Hayashi T. Presynaptic L-type $\mathrm{Ca}^{2+}$ channels on excessive dopamine release from rat caudate putamen. Physiology \& Behavior. 2000; 68:641-649. [PubMed: 10764893]

Oz S, Tsemakhovich V, Christel CJ, Lee A, Dascal N. CaBP1 regulates voltage-dependent inactivation and activation of $\mathrm{Ca}_{\mathrm{V}} 1.2$ (L-type) calcium channels. Journal of Biological Chemistry. 2011; 286:13945-13953. [PubMed: 21383011]

Pang L, Koren G, Wang Z, Nattel S. Tissue-specific expression of two human $\mathrm{Ca}_{\mathrm{V}} 1.2$ isoforms under the control of distinct $5^{\prime}$ flanking regulatory elements. FEBS Letters. 2003; 546:349-354. [PubMed: 12832067]

Pazzaglia PJ, Post RM, Ketter TA, Callahan AM, Marangell LB, Frye MA, George MS, Kimbrell TA, Leverich GS, Cora-Locatelli G, Luckenbaugh D. Nimodipine monotherapy and carbamazepine augmentation in patients with refractory recurrent affective illness. Journal of Clinical Psychopharmacology. 1998; 18:404-413. [PubMed: 9790159]

Pe'er I, Yelensky R, Altshuler D, Daly MJ. Estimation of the multiple testing burden for genomewide association studies of nearly all common variants. Genetic Epidemiology. 2008; 32:381-385. [PubMed: 18348202]

Perez-Reyes E, Wei X, Castellano A, Birnbaumer L. Molecular diversity of L-type calcium channels Evidence for alternative splicing of the transcripts of three non-allelic genes. Journal of Biological Chemistry. 1990a; 265:20430-20436. [PubMed: 2173707] 
Perez-Reyes E, Wei XY, Castellano A, Birnbaumer L. Molecular diversity of L-type calcium channels Evidence for alternative splicing of the transcripts of three non-allelic genes. Journal of Biological Chemistry. 1990b; 265:20430-20436. [PubMed: 2173707]

Perova T, Wasserman MJ, Li PP, Warsh JJ. Hyperactive intracellular calcium dynamics in B lymphoblasts from patients with bipolar I disorder. International Journal of Neuropsychopharmacology. 2008; 11:185-196. [PubMed: 17681086]

Perrier E, Pompei F, Ruberto G, Vassos E, Collier D, Frangou S. Initial evidence for the role of CACNA1C on subcortical brain morphology in patients with bipolar disorder. European Psychiatry. 2011; 26:135-137. [PubMed: 21292451]

Perrot-Sinal TS, Auger AP, McCarthy MM. Excitatory actions of GABA in developing brain are mediated by L-type $\mathrm{Ca}^{2+}$ channels and dependent on age, sex, and brain region. Neuroscience. 2003; 116:995-1003. [PubMed: 12617940]

Perrot-Sinal TS, Davis AM, Gregerson KA, Kao JP, McCarthy MM. Estradiol enhances excitatory gamma-aminobutyric [corrected] acid-mediated calcium signaling in neonatal hypothalamic neurons. Endocrinology. 2001; 142:2238-2243. [PubMed: 11356668]

Pierce RC, Kumaresan V. The mesolimbic dopamine system: the final common pathway for the reinforcing effect of drugs of abuse? Neuroscience \& Biobehavioral Reviews. 2006; 30:215-238. [PubMed: 16099045]

Powers PA, Gregg RG, Lalley PA, Liao M, Hogan K. Assignment of the human gene for the $a_{1}$ subunit of the cardiac DHP-sensitive $\mathrm{Ca}^{2+}$ channel (CCHL1A1) to chromosome 12p12-pter. Genomics. 1991; 10:835-839. [PubMed: 1653763]

Pucilowski O, Plaznik A, Overstreet DH. Isradipine suppresses amphetamine-induced conditioned place preference and locomotor stimulation in the rat. Neuropsychopharmacology. 1995; 12:239244. [PubMed: 7612157]

Quinn EM, Hill M, Anney R, Gill M, Corvin AP, Morris DW. Evidence for cis-acting regulation of ANK3 and CACNA1C gene expression. Bipolar Disorder. 2010; 12:440-445.

Radua J, Surguladze SA, Marshall N, Walshe M, Bramon E, Collier DA, Prata DP, Murray RM, McDonald C. The impact of CACNA1C allelic variation on effective connectivity during emotional processing in bipolar disorder. Molecular Psychiatry. 2012

Rajadhyaksha A. L-type $\mathrm{Ca}^{2+}$ channels mediate adaptation of extracellular signal-regulated kinase 1/2 phosphorylation in the ventral tegmental area after chronic amphetamine treatment. Journal of Neuroscience. 2004; 24:7464-7476. [PubMed: 15329393]

Reich DE, Cargill M, Bolk S, Ireland J, Sabeti PC, Richter DJ, Lavery T, Kouyoumjian R, Farhadian SF, Ward R, Lander ES. Linkage disequilibrium in the human genome. Nature. 2001; 411:199204. [PubMed: 11346797]

Ripke S, Sanders AR, Kendler KS, Levinson DF, Sklar P, Holmans PA, Lin DY, Duan J, Ophoff RA, Andreassen OA, Scolnick E, Cichon S, St Clair D, Corvin A, Gurling H, Werge T, Rujescu D, Blackwood DH, Pato CN, Malhotra AK, Purcell S, Dudbridge F, Neale BM, Rossin L, Visscher PM, Posthuma D, Ruderfer DM, Fanous A, Stefansson H, Steinberg S, Mowry BJ, Golimbet V, De Hert M, Jonsson EG, Bitter I, Pietilainen OP, Collier DA, Tosato S, Agartz I, Albus M, Alexander M, Amdur RL, Amin F, Bass N, Bergen SE, Black DW, Borglum AD, Brown MA, Bruggeman R, Buccola NG, Byerley WF, Cahn W, Cantor RM, Carr VJ, Catts SV, Choudhury K, Cloninger CR, Cormican P, Craddock N, Danoy PA, Datta S, de Haan L, Demontis D, Dikeos D, Djurovic S, Donnelly P, Donohoe G, Duong L, Dwyer S, Fink-Jensen A, Freedman R, Freimer NB, Friedl M, Georgieva L, Giegling I, Gill M, Glenthoj B, Godard S, Hamshere M, Hansen M, Hansen T, Hartmann AM, Henskens FA, Hougaard DM, Hultman CM, Ingason A, Jablensky AV, Jakobsen KD, Jay M, Jurgens G, Kahn RS, Keller MC, Kenis G, Kenny E, Kim Y, Kirov GK, Konnerth H, Konte B, Krabbendam L, Krasucki R, Lasseter VK, Laurent C, Lawrence J, Lencz T, Lerer FB, Liang KY, Lichtenstein P, Lieberman JA, Linszen DH, Lonnqvist J, Loughland CM, Maclean AW, Maher BS, Maier W, Mallet J, Malloy P, Mattheisen M, Mattingsdal M, McGhee KA, McGrath JJ, McIntosh A, McLean DE, McQuillin A, Melle I, Michie PT, Milanova V, Morris DW, Mors O, Mortensen PB, Moskvina V, Muglia P, MyinGermeys I, Nertney DA, Nestadt G, Nielsen J, Nikolov I, Nordentoft M, Norton N, Nothen MM, O’Dushlaine CT, Olincy A, Olsen L, O’Neill FA, Orntoft TF, Owen MJ, Pantelis C, Papadimitriou G, Pato MT, Peltonen L, Petursson H, Pickard B, Pimm J, Pulver AE, Puri V, 
Quested D, Quinn EM, Rasmussen HB, Rethelyi JM, Ribble R, Rietschel M, Riley BP, Ruggeri M, Schall U, Schulze TG, Schwab SG, Scott RJ, Shi J, Sigurdsson E, Silverman JM, Spencer CC, Stefansson K, Strange A, Strengman E, Stroup TS, Suvisaari J, Terenius L, Thirumalai S, Thygesen JH, Timm S, Toncheva D, van den Oord E, van Os J, van Winkel R, Veldink J, Walsh D, Wang AG, Wiersma D, Wildenauer DB, Williams HJ, Williams NM, Wormley B, Zammit S, Sullivan PF, O’Donovan MC, Daly MJ, Gejman PV. Genome-wide association study identifies five new schizophrenia loci. Nature Genetics. 2011; 43:969-976. [PubMed: 21926974]

Rose EJ, Donohoe G. Brain vs behavior: an effect size comparison of neuroimaging and cognitive studies of genetic risk for schizophrenia. Schizophrenia Bulletin. 2012

Roussos P, Giakoumaki SG, Georgakopoulos A, Robakis NK, Bitsios P. The CACNA1C and ANK3 risk alleles impact on affective personality traits and startle reactivity but not on cognition or gating in healthy males. Bipolar Disorder. 2011; 13:250-259.

Sandler VM, Barbara JG. Calcium-induced calcium release contributes to action potential-evoked calcium transients in hippocampal CA1 pyramidal neurons. Journal of Neuroscience. 1999; 19:4325-4336. [PubMed: 10341236]

Sarkar SN, Huang RQ, Logan SM, Yi KD, Dillon GH, Simpkins JW. Estrogens directly potentiate neuronal L-type $\mathrm{Ca}^{2+}$ channels. Proceedings of the National Academy of Sciences USA. 2008; 105:15148-15153.

Schierberl K, Hao J, Tropea TF, Ra S, Giordano TP, Xu Q, Garraway SM, Hofmann F, Moosmang S, Striessnig J, Inturrisi CE, Rajadhyaksha AM. $\mathrm{Ca}_{\mathrm{V}} 1.2$ L-type $\mathrm{Ca}^{2+}$ channels mediate cocaineinduced GluA1 trafficking in the nucleus accumbens, a long-term adaptation dependent on ventral tegmental area $\mathrm{Ca}_{\mathrm{v}} 1.3$ channels. Journal of Neuroscience. 2011; 31:13562-13575. [PubMed: 21940447]

Schultz D, Mikala G, Yatani A, Engle DB, Iles DE, Segers B, Sinke RJ, Weghuis DO, Klockner U, Wakamori M, et al. Cloning, chromosomal localization, and functional expression of the $\mathrm{a}_{1}$ subunit of the L-type voltage-dependent calcium channel from normal human heart. Proceedings of the National Academy of Sciences USA. 1993; 90:6228-6232.

Seisenberger C, Specht V, Welling A, Platzer J, Pfeifer A, Kuhbandner S, Striessnig J, Klugbauer N, Feil R, Hofmann F. Functional embryonic cardiomyocytes after disruption of the L-type $\mathrm{a}_{1 \mathrm{C}}$ $\left(\mathrm{Ca}_{\mathrm{v}} 1.2\right)$ calcium channel gene in the mouse. Journal of Biological Chemistry. 2000; 275:3919339199. [PubMed: 10973973]

Shi C, Soldatov NM. Molecular determinants of voltage-dependent slow inactivation of the $\mathrm{Ca}^{2+}$ channel. Journal of Biological Chemistry. 2002; 277:6813-6821. [PubMed: 11751866]

Shi J, Potash JB, Knowles JA, Weissman MM, Coryell W, Scheftner WA, Lawson WB, DePaulo JR Jr, Gejman PV, Sanders AR, Johnson JK, Adams P, Chaudhury S, Jancic D, Evgrafov O, Zvinyatskovskiy A, Ertman N, Gladis M, Neimanas K, Goodell M, Hale N, Ney N, Verma R, Mirel D, Holmans P, Levinson DF. Genome-wide association study of recurrent early-onset major depressive disorder. Molecular Psychiatry. 2011; 16:193-201. [PubMed: 20125088]

Shibasaki M, Kurokawa K, Ohkuma S. Upregulation of L-type $\mathrm{Ca}_{\mathrm{V}} 1$ channels in the development of psychological dependence. Synapse. 2010; 64:440-444. [PubMed: 20169575]

Shinnick-Gallagher P, McKernan MG, Xie J, Zinebi F. L-type voltage-gated calcium channels are involved in the in vivo and in vitro expression of fear conditioning. Annals of the New York Academy of Sciences. 2003; 985:135-149. [PubMed: 12724155]

Sinnegger-Brauns MJ, Hetzenauer A, Huber IG, Renstrom E, Wietzorrek G, Berjukov S, Cavalli M, Walter D, Koschak A, Waldschutz R, Hering S, Bova S, Rorsman P, Pongs O, Singewald N, Striessnig JJ. Isoform-specific regulation of mood behavior and pancreatic beta cell and cardiovascular function by L-type $\mathrm{Ca}^{2+}$ channels. Journal of Clinical Investigation. 2004; 113:1430-1439. [PubMed: 15146240]

Sinnegger-Brauns MJ, Huber IG, Koschak A, Wild C, Obermair GJ, Einzinger U, Hoda JC, Sartori $\mathrm{SB}$, Striessnig J. Expression and 1,4-dihydropyridine-binding properties of brain L-type calcium channel isoforms. Molecular Pharmacology. 2009; 75:407-414. [PubMed: 19029287]

Sklar P, Gabriel SB, McInnis MG, Bennett P, Lim YM, Tsan G, Schaffner S, Kirov G, Jones I, Owen M, Craddock N, DePaulo JR, Lander ES. Family-based association study of 76 candidate genes in bipolar disorder: BDNF is a potential risk locus. Brain-derived neutrophic factor. Molecular Psychiatry. 2002; 7:579-593. [PubMed: 12140781] 
Sklar P, Ripke S, Scott LJ, Andreassen OA, Cichon S, Craddock N, Edenberg HJ, Nurnberger JI Jr, Rietschel M, Blackwood D, Corvin A, Flickinger M, Guan W, Mattingsdal M, McQuillin A, Kwan P, Wienker TF, Daly M, Dudbridge F, Holmans PA, Lin D, Burmeister M, Greenwood TA, Hamshere ML, Muglia P, Smith EN, Zandi PP, Nievergelt CM, McKinney R, Shilling PD, Schork NJ, Bloss CS, Foroud T, Koller DL, Gershon ES, Liu C, Badner JA, Scheftner WA, Lawson WB, Nwulia EA, Hipolito M, Coryell W, Rice J, Byerley W, McMahon FJ, Schulze TG, Berrettini W, Lohoff FW, Potash JB, Mahon PB, McInnis MG, Zollner S, Zhang P, Craig DW, Szelinger S, Barrett TB, Breuer R, Meier S, Strohmaier J, Witt SH, Tozzi F, Farmer A, McGuffin P, Strauss J, Xu W, Kennedy JL, Vincent JB, Matthews K, Day R, Ferreira MA, O’Dushlaine C, Perlis R, Raychaudhuri S, Ruderfer D, Hyoun PL, Smoller JW, Li J, Absher D, Thompson RC, Meng FG, Schatzberg AF, Bunney WE, Barchas JD, Jones EG, Watson SJ, Myers RM, Akil H, Boehnke M, Chambert K, Moran J, Scolnick E, Djurovic S, Melle I, Morken G, Gill M, Morris D, Quinn E, Muhleisen TW, Degenhardt FA, Mattheisen M, Schumacher J, Maier W, Steffens M, Propping P, Nothen MM, Anjorin A, Bass N, Gurling H, Kandaswamy R, Lawrence J, McGhee K, McIntosh A, McLean AW, Muir WJ, Pickard BS, Breen G, St Clair D, Caesar S, Gordon-Smith K, Jones L, Fraser C, Green EK, Grozeva D, Jones IR, Kirov G, Moskvina V, Nikolov I, O'Donovan MC, Owen MJ, Collier DA, Elkin A, Williamson R, Young AH, Ferrier IN, Stefansson K, Stefansson H, Thornorgeirsson T, Steinberg S, Gustafsson O, Bergen SE, Nimgaonkar V, Hultman C, Landen M, Lichtenstein P, Sullivan P, Schalling M, Osby U, Backlund L, Frisen L, Langstrom N, Jamain S, Leboyer M, Etain B, Bellivier F, Petursson H, Sigur Sson E, Muller-Mysok B, Lucae S, Schwarz M, Schofield PR, Martin N, Montgomery GW, Lathrop M, Oskarsson H, Bauer M, Wright A, Mitchell PB, Hautzinger M, Reif A, Kelsoe JR, Purcell SM. Large-scale genome-wide association analysis of bipolar disorder identifies a new susceptibility locus near ODZ4. Nature Genetics. 2011; 43:977-983. [PubMed: 21926972]

Sklar P, Smoller JW, Fan J, Ferreira MAR, Perlis RH, Chambert K, Nimgaonkar VL, McQueen MB, Faraone SV, Kirby A, de Bakker PIW, Ogdie MN, Thase ME, Sachs GS, Todd-Brown K, Gabriel SB, Sougnez C, Gates C, Blumenstiel B, Defelice M, Ardlie KG, Franklin J, Muir WJ, McGhee KA, MacIntyre DJ, McLean A, VanBeck M, McQuillin A, Bass NJ, Robinson M, Lawrence J, Anjorin A, Curtis D, Scolnick EM, Daly MJ, Blackwood DH, Gurling HM, Purcell SM. Whole-genome association study of bipolar disorder. Molecular Psychiatry. 2008; 13:558569. [PubMed: 18317468]

Slatkin M. Linkage disequilibrium-understanding the evolutionary past and mapping the medical future. Nature Reviews Genetics. 2008; 9:477-485.

Small SA, Schobel SA, Buxton RB, Witter MP, Barnes CA. A pathophysiological framework of hippocampal dysfunction in ageing and disease. Nature Reviews Neuroscience. 2011; 12:585601.

Soeiro-de-Souza MG, Otaduy MC, Dias CZ, Bio DS, Machado-Vieira R, Moreno RA. The impact of the CACNA1C risk allele on limbic structures and facial emotions recognition in bipolar disorder subjects and healthy controls. Journal of Affective Disorders. 2012

Soldatov NM. Molecular diversity of L-type $\mathrm{Ca}^{2+}$ channel transcripts in human fibroblasts. Proceedings of the National Academy of Sciences USA. 1992; 89:4628-4632.

Soldatov NM. Genomic structure of human L-type $\mathrm{Ca}^{2+}$ channel. Genomics. 1994; 22:77-87. [PubMed: 7959794]

Schwartz PJ, Timothy KW, Decher N, Kumar P, Sachse FB, Beggs AH, Sanguinetti MC, Keating MT. Severe arrhythmia disorder caused by cardiac L-type calcium channel mutations. Proceedings of the National Academy of Sciences USA. 2005; 102:8089-8096. (discussion 8086-8088).

Splawski I, Timothy KW, Sharpe LM, Decher N, Kumar P, Bloise R, Napolitano C, Schwartz PJ, Joseph RM, Condouris K, Tager-Flusberg H, Priori SG, Sanguinetti MC, Keating MT. Ca 1.2 calcium channel dysfunction causes a multisystem disorder including arrhythmia and autism. Cell. 2004; 119:19-31. [PubMed: 15454078]

Strohmaier J, Amelang M, Hothorn LA, Witt SH, Nieratschker V, Gerhard D, Meier S, Wüst S, Frank J, Loerbroks A, Rietschel M, Stürmer T, Schulze TG. The psychiatric vulnerability gene CACNA1C and its sex-specific relationship with personality traits, resilience factors and depressive symptoms in the general population. Mol Psychiatry. 2012 [Epub ahead of print].

Subramanian J, Morozov A. Erk1/2 inhibit synaptic vesicle exocytosis through L-type calcium channels. Journal of Neuroscience. 2011; 31:4755-4764. [PubMed: 21430174] 
Sullivan PF, de Geus EJ, Willemsen G, James MR, Smit JH, Zandbelt T, Arolt V, Baune BT, Blackwood D, Cichon S, Coventry WL, Domschke K, Farmer A, Fava M, Gordon SD, He Q, Heath AC, Heutink P, Holsboer F, Hoogendijk WJ, Hottenga JJ, Hu Y, Kohli M, Lin D, Lucae S, Macintyre DJ, Maier W, McGhee KA, McGuffin P, Montgomery GW, Muir WJ, Nolen WA, Nothen MM, Perlis RH, Pirlo K, Posthuma D, Rietschel M, Rizzu P, Schosser A, Smit AB, Smoller JW, Tzeng JY, van Dyck R, Verhage M, Zitman FG, Martin NG, Wray NR, Boomsma DI, Penninx BW. Genome-wide association for major depressive disorder: a possible role for the presynaptic protein piccolo. Molecular Psychiatry. 2009; 14:359-375. [PubMed: 19065144]

Suzuki A, Josselyn SA, Frankland PW, Masushige S, Silva AJ, Kida S. Memory reconsolidation and extinction have distinct temporal and biochemical signatures. Journal of Neuroscience. 2004; 24:4787-4795. [PubMed: 15152039]

Tabuchi A, Nakaoka R, Amano K, Yukimine M, Andoh T, Kuraishi Y, Tsuda M. Differential activation of brain-derived neurotrophic factor gene promoters I and III by $\mathrm{Ca}^{2+}$ signals evoked via L-type voltage-dependent and N-methyl-D-aspartate receptor $\mathrm{Ca}^{2+}$ channels. Journal of Biological Chemistry. 2000; 275:17269-17275. [PubMed: 10748141]

Tanabe T, Takeshima H, Mikami A, Flockerzi V, Takahashi H, Kangawa K, Kojima M, Matsuo H, Hirose T, Numa S. Primary structure of the receptor for calcium channel blockers from skeletal muscle. Nature. 1987; 328:313-318. [PubMed: 3037387]

Tang ZZ, Liang MC, Lu S, Yu D, Yu CY, Yue DT, Soong TW. Transcript scanning reveals novel and extensive splice variations in human L-type voltage-gated calcium channel $\mathrm{Ca}_{\mathrm{V}} 1.2$ alpha1 subunit. Journal of Biological Chemistry. 2004; 279:44335-44343. [PubMed: 15299022]

Tang ZZ, Zheng S, Nikolic J, Black DL. Developmental control of $\mathrm{Ca}_{\mathrm{V}} 1.2$ L-type calcium channel splicing by Fox proteins. Molecular and Cellular Biology. 2009; 29:4757-4765. [PubMed: 19564422]

Taragano FE, Allegri R, Vicario A, Bagnatti P, Lyketsos CG. A double blind, randomized clinical trial assessing the efficacy and safety of augmenting standard antidepressant therapy with nimodipine in the treatment of 'vascular depression'. International Journal Of Geriatric Psychiatry. 2001; 16:254-260. [PubMed: 11288158]

Taragano FE, Bagnatti P, Allegri RF. A double-blind, randomized clinical trial to assess the augmentation with nimodipine of antidepressant therapy in the treatment of vascular depression. International Psychogeriatric. 2005; 17:487-498.

Thimm M, Kircher T, Kellermann T, Markov V, Krach S, Jansen A, Zerres K, Eggermann T, Stocker T, Shah NJ, Nothen MM, Rietschel M, Witt SH, Mathiak K, Krug A. Effects of a CACNA1C genotype on attention networks in healthy individuals. Psychological Medicine. 2011; 41:15511561. [PubMed: 21078228]

Tiwari S, Zhang Y, Heller J, Abernethy DR, Soldatov NM. Atherosclerosis-related molecular alteration of the human $\mathrm{Ca}_{\mathrm{v}} 1.2$ calcium channel $\mathrm{a}_{1 \mathrm{C}}$ subunit. PNAS. 2006; 103:17024-17029. [PubMed: 17071743]

Triggle, D. Biochemical and pharmacologic difference among calcium channel antagonists: clinical implications. In: Epstein, M., editor. Calcium Antagonists in Clinical Medicine. Hanley \& Belfus; Philadelphia: 1992. p. 1-27.

Viveros MP, Martin S, Ormazabal MJ, Alfaro MJ, Martin MI. Effects of nimodipine and nifedipine upon behavior and regional brain monoamines in the rat. Psychopharmacology (Berl). 1996; 127:123-132. [PubMed: 8888378]

Wang D, Papp AC, Binkley PF, Johnson JA, Sadee W. Highly variable mRNA expression and splicing of L-type voltage-dependent calcium channel a subunit 1C in human heart tissues. Pharmacogenetics Genomics. 2006; 16:735-745.

Wang F, McIntosh AM, He Y, Gelernter J, Blumberg HP. The association of genetic variation in CACNA1C with structure and function of a frontotemporal system. Bipolar Disorder. 2011; 13:696-700.

Weick JP, Groth RD, Isaksen AL, Mermelstein PG. Interactions with PDZ proteins are required for Ltype calcium channels to activate cAMP response element-binding protein-dependent gene expression. Journal of Neuroscience. 2003; 23:3446-3456. [PubMed: 12716953] 
Wessa M, Linke J, Witt SH, Nieratschker V, Esslinger C, Kirsch P, Grimm O, Hennerici MG, Gass A, King AV, Rietschel M. The CACNA1C risk variant for bipolar disorder influences limbic activity. Molecular Psychiatry. 2010; 15:1126-1127. [PubMed: 20351721]

West AE, Chen WG, Dalva MB, Dolmetsch RE, Kornhauser JM, Shaywitz AJ, Takasu MA, Tao X, Greenberg ME. Calcium regulation of neuronal gene expression. Proceedings of the National Academy of Sciences USA. 2001; 98:11024-11031.

Wheeler DG, Barrett CF, Groth RD, Safa P, Tsien RW. CaMKII locally encodes L-type channel activity to signal to nuclear CREB in excitation-transcription coupling. Journal of Cell Biology. 2008; 183:849-863. [PubMed: 19047462]

White JA, McKinney BC, John MC, Powers PA, Kamp TJ, Murphy GG. Conditional forebrain deletion of the L-type calcium channel $\mathrm{Ca}_{\mathrm{V}} 1.2$ disrupts remote spatial memories in mice. Learning \& Memory. 2008; 15:1-5. [PubMed: 18174367]

Williams HJ, Craddock N, Russo G, Hamshere ML, Moskvina V, Dwyer S, Smith RL, Green E, Grozeva D, Holmans P, Owen MJ, O’Donovan MC. Most genome-wide significant susceptibility loci for schizophrenia and bipolar disorder reported to date cross-traditional diagnostic boundaries. Human Molecular Genetics. 2011; 20:387-391. [PubMed: 21037240]

Yan H, Yuan W, Velculescu VE, Vogelstein B, Kinzler KW. Allelic variation in human gene expression. Science. 2002; 297:1143. [PubMed: 12183620]

Yang L, Wang Z, Wang B, Justice NJ, Zheng H. Amyloid precursor protein regulates $\mathrm{Ca}_{\mathrm{V}} 1.2$ L-type calcium channel levels and function to influence GABAergic short-term plasticity. Journal of Neuroscience. 2009; 29:15660-15668. [PubMed: 20016080]

Yoshii M, Watabe S. Enhancement of neuronal calcium channel currents by the nootropic agent, nefiracetam (DM-9384), in NG108-15 cells. Brain Research. 1994; 642:123-131. [PubMed: 8032872]

Zhang Q, Shen Q, Xu Z, Chen M, Cheng L, Zhai J, Gu H, Bao X, Chen X, Wang K, Deng X, Ji F, Liu C, Li J, Dong Q, Chen C. The effects of CACNA1C gene polymorphism on spatial working memory in both healthy controls and patients with schizophrenia or bipolar disorder. Neuropsychopharmacology. 2011

Zhou H, Kim SA, Kirk EA, Tippens AL, Sun H, Haeseleer F, Lee A. Ca2+-binding protein-1 facilitates and forms a postsynaptic complex with $\mathrm{Ca}_{\mathrm{v}} 1.2$ (L-type) $\mathrm{Ca}^{2+}$ channels. Journal of Neuroscience. 2004; 24:4698-4708. [PubMed: 15140941]

Zuccotti A, Clementi S, Reinbothe T, Torrente A, Vandael DH, Pirone A. Structural and functional differences between L-type calcium channels: crucial issues for future selective targeting. Trends in Pharmacological Sciences. 2011; 32:366-375. [PubMed: 21450352]

Zuhlke RD, Pitt GS, Deisseroth K, Tsien RW, Reuter H. Calmodulin supports both inactivation and facilitation of L-type calcium channels. Nature. 1999; 399:159-162. [PubMed: 10335846] 


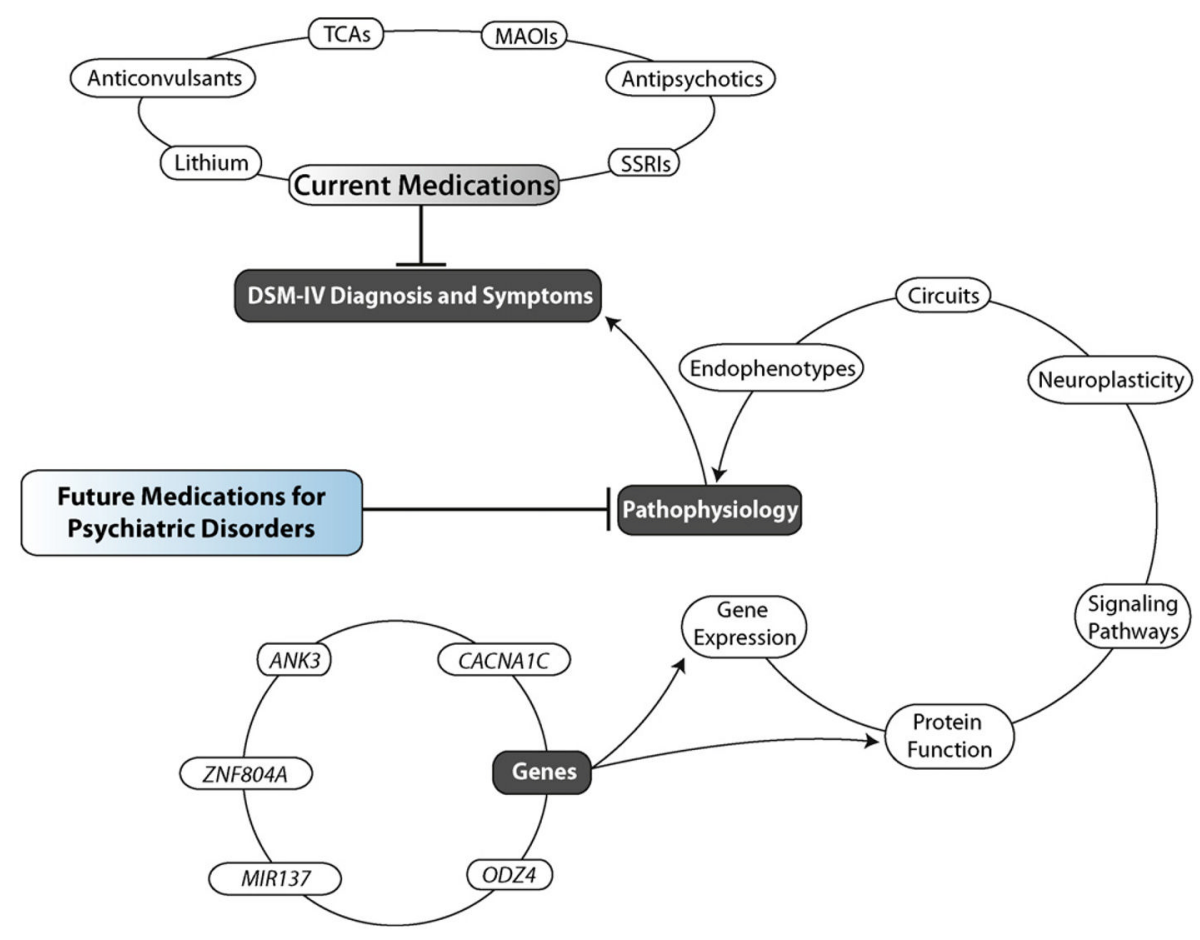

Fig. 1. Psychiatric disorders and their relationship with susceptibility genes, physiological factors, current classes of drugs, and possible novel treatments

Current treatments for psychiatric disorders were developed to treat symptoms, and in many instances likely have limited effects on underlying pathophysiology. It is hoped that treatments targeted toward pathophysiology will provide greater and sustained rates of remission. However, currently knowledge is lacking regarding the pathophysiology of most psychiatric diseases. Treatments that target the underlying pathophysiology of psychiatric disorders such as mood disorders will derive from understanding the neurobiology underlying the disease. As diseases with high heritability, genetic underpinnings are a link to pathophysiology. The top portion of the figure shows current treatments. The bottom portion of the figure indicates examples of current top genetic findings in psychiatric disorders, including $C A C N A 1 C$. The middle portion of the figure suggests levels of analysis that will be critical to understand the role of genetic variation on disease pathopysiology and to direct the subsequent development of future treatments. MAOI, Monoamine oxidase inhibitor; SSRI, Selective serotonin reuptake inhibitor; TCA, Tricyclic antidepressant; $A N K 3$, ankyrin 3, node of Ranvier (ankyrin G); CACNA1C: voltage-dependent L type calcium channel, a1C subunit; $M I R 137$, microRNA 137; ODZ4, odd Oz/ten-m homolog 4 (Drosophila); ZNF804A, zinc finger protein 804A. 


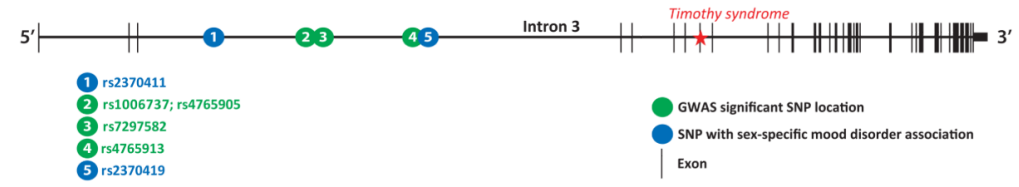

Fig. 2. Mental disorder significant findings projected on the genomic map of CACNA1C Genomic map of $C A C N A 1 C$ beginning with exon 1 (Soldatov, 1994); exons are indicated with vertical bars separated by introns. Identified mental disorder associated SNPs are shown by colored circles at approximate locations on the gene. GWAS significant associations are: rs1006737 and rs4765905 (which are in complete LD)_bipolar disorder, schizophrenia, and major depression. rs4765913 - bipolar disorder and schizophrenia/ bipolar disorder combined analysis. rs7297582 - bipolar disorder and major depression disorder combined analysis. rs2370411 and rs2370419: two SNPs showing sex specific association (females only). The red $\operatorname{star}(*)$ at exon 8/8a marks the Timothy syndrome loci. The image is of transcript variant 1, initially referred to as HFCC (Soldatov, 1992, GenBank accession \#: NM_199460.2); not shown in the figure is alternative splicing of the gene. 
Table 1

\section{Genetic evidence associating CACNA1C with mental disorders}

Bipolar Disorder (BPD), Schizophrenia (SZ), and Major Depressive Disorder (MDD). Odds Ratios (OR) are listed where available. Genome Wide Association Study (GWAS); Sequenced treatment alternatives to relieve depression $($ STAR $*$ D) study.

\begin{tabular}{|c|c|c|c|c|}
\hline $\begin{array}{l}\text { SNP/Region (within } \\
\text { intron } 3 \text { unless } \\
\text { otherwise noted) }\end{array}$ & Association with/comments & Study participants & $\begin{array}{l}\text { Statistics (uncorrected } \\
\text { unless otherwise } \\
\text { noted) }\end{array}$ & Reference \\
\hline $\begin{array}{l}\text { rs } 72552065 \\
\text { (WIAF-13171) Exon } 44\end{array}$ & BPD (Nominal) & 136 parent-proband trios & $p=0.011$ & $\begin{array}{l}\text { Sklar et al. } \\
(2002)\end{array}$ \\
\hline Exon $8 \& 8 \mathrm{a}$ & $\begin{array}{l}\text { Timothy syndrome, a multisystem } \\
\text { syndrome including autistic } \\
\text { features }\end{array}$ & 19 affected children & Causative mutation & $\begin{array}{l}\text { Splawski et al. } \\
(2005,2004)\end{array}$ \\
\hline rs 1006737 & BPD; GWAS & $1461 \mathrm{BPD}, 2008$ controls $^{a}$ & $p=1 \times 10^{-4}, \mathrm{OR}=1.21$ & $\begin{array}{l}\text { Sklar et al. } \\
(2008)\end{array}$ \\
\hline rs 1006737 & BPD; GWAS & $4387 \mathrm{BPD}, 6209$ controls $^{a}$ & $p=7 \times 10^{-8}, \mathrm{OR}=1.18$ & $\begin{array}{l}\text { Ferreira et al. } \\
(2008)\end{array}$ \\
\hline$C A C N A 1 C$ & $\begin{array}{l}\text { BPD; Gene-wide significance was } \\
\text { assessed in genome-wide data } \\
\text { rather than at SNP level }\end{array}$ & $\begin{array}{l}1868 \mathrm{BPD}, 479 \mathrm{SZ}, \& 2938 \\
\text { controls }^{a}\end{array}$ & $\begin{array}{l}\text { Gene-wide } p_{\min }=7 \times \\
10^{-4} \text { (Min } p \text { value for a } \\
\text { gene to be significant at } \\
\text { genome-wide level) }\end{array}$ & $\begin{array}{l}\text { Moskvina et al. } \\
\text { (2009) }\end{array}$ \\
\hline $\begin{array}{l}4 \text { independent signals } \\
\text { (including rs 1006737) }\end{array}$ & $\begin{array}{l}\text { BPD; BPD GWAS data analyzed } \\
\text { with lower threshold for } \\
\text { significance }\end{array}$ & 1865 BPD, 14,297 controls ${ }^{a}$ & $\begin{array}{l}\text { Minimum } p \text { value was } \\
\text { set at } p=1.5 \times 10^{-4}\end{array}$ & $\begin{array}{l}\text { Keers et al. } \\
(2009)\end{array}$ \\
\hline$C A C N A 1 C$ & $\begin{array}{l}\text { MDD; GWAS; reported the p-value } \\
\text { for the entire gene and not for a } \\
\text { specific SNP }\end{array}$ & 4387 MDD, 6209 controls $^{a}$ & $p=0.03$ & $\begin{array}{l}\text { Sullivan et al. } \\
(2009)\end{array}$ \\
\hline rs2370419; rs2370411 & $\begin{array}{l}\text { SNPs in the genomic region of } \\
C A C N A 1 C \text { analyzed. Significant } \\
\text { interaction with sex. Increased risk } \\
\text { of mood disorder (BPD and MDD) } \\
\text { in females only }\end{array}$ & $\begin{array}{l}2021 \text { Mood disorder cases } \\
\text { (1001 BPD \& } 1020 \text { MDD), } \\
1840 \text { controls }\end{array}$ & $\begin{array}{l}\text { rs2370419: } p=1.4 \times \\
10^{-4}, \mathrm{OR}=1.64 \\
\mathrm{rs} 2370411: p=2.1 \times \\
10^{-4}, \mathrm{OR}=1.32\end{array}$ & $\begin{array}{l}\text { Dao et al. } \\
(2010)\end{array}$ \\
\hline rs1006737 & $\mathrm{SZ}$ & $282 \mathrm{SZ}, 440$ controls & $p=0.03, \mathrm{OR}=1.77$ & $\begin{array}{l}\text { Bigos et al. } \\
(2010)\end{array}$ \\
\hline rs1006737; rs10848635 & $\begin{array}{l}\text { Increased risk of treatment- } \\
\text { emergent suicidality in non- } \\
\text { psychotic MDD }\end{array}$ & $\begin{array}{l}1213 \mathrm{MDD}(\mathrm{STAR} * \mathrm{D} \\
\text { study) }\end{array}$ & $\begin{array}{l}\mathrm{rs} 1006737: p=0.02 \\
\mathrm{OR}=1.34 ; \mathrm{rs} 10848635 \\
p=0.04, \mathrm{OR}=1.29\end{array}$ & $\begin{array}{l}\text { Casamassima et } \\
\text { al. }(2010 \mathrm{~b})\end{array}$ \\
\hline rs1006737 & $\mathrm{SZ}$ & 976 SZ, 1489 controls & $p=0.015, \mathrm{OR}=1.16$ & $\begin{array}{l}\text { Nyegaard et al. } \\
(2010)\end{array}$ \\
\hline rs 1006737 & SZ and MDD & $\begin{array}{l}479 \mathrm{SZ}, 1196 \mathrm{MDD}, 15316 \\
\text { controls }^{a}\end{array}$ & $\begin{array}{l}p=0.034, \mathrm{OR}=1.15 \\
(\mathrm{SZ}), p=0.013, \mathrm{OR}= \\
1.15(\mathrm{MDD})\end{array}$ & $\begin{array}{l}\text { Green et al. } \\
(2010)\end{array}$ \\
\hline rs 1006737 & $\begin{array}{l}\text { Higher psychopathology scores for } \\
\text { depression, anxiety, obsessive- } \\
\text { compulsive thoughts, interpersonal } \\
\text { sensitivity, and neuroticism on } \\
\text { Beck Depression Inventory or State } \\
\text { Trait Anxiety Inventory }\end{array}$ & 110 healthy volunteers & $p<0.05$ & Erk et al. (2010) \\
\hline rs 1006737 & $\begin{array}{l}\text { Lower extraversion and higher } \\
\text { harm avoidance, trait anxiety, and } \\
\text { paranoid ideation scores as } \\
\text { assessed via personality } \\
\text { questionnaires }\end{array}$ & 530 healthy volunteers & $p<0.05$ (corrected) & $\begin{array}{l}\text { Roussos et al. } \\
\text { (2011) }\end{array}$ \\
\hline rs 1006737 & $\begin{array}{l}\text { Higher depressive and manic } \\
\text { symptom scores among all groups }\end{array}$ & $\begin{array}{l}41 \mathrm{BPD}, 25 \text { unaffected first } \\
\text { degree relatives, } 50 \text { controls }\end{array}$ & $p=0.01$ & $\begin{array}{l}\text { Jogia et al. } \\
(2011)\end{array}$ \\
\hline rs7297582; rs1006737 & $\begin{array}{l}\text { Combined population of BPD and } \\
\text { MDD in a meta analysis; GWAS }\end{array}$ & $\begin{array}{l}10596 \mathrm{BPD}+\mathrm{MDD}, 3456 \\
\text { controls }^{a}\end{array}$ & $\begin{array}{l}\text { rs7297582: } p=3.4 \times \\
10^{-8}, \text { rs } 1006737: p=3.1 \\
\times 10^{-8}, \text { OR for }\end{array}$ & Liu et al. (2011) \\
\hline
\end{tabular}




\begin{tabular}{|c|c|c|c|c|}
\hline $\begin{array}{l}\text { SNP/Region (within } \\
\text { intron } 3 \text { unless } \\
\text { otherwise noted) }\end{array}$ & Association with/comments & Study participants & $\begin{array}{l}\text { Statistics (uncorrected } \\
\text { unless otherwise } \\
\text { noted) }\end{array}$ & Reference \\
\hline & & & $\begin{array}{l}\text { rs1006737 = } 1.18 \\
(\mathrm{BPD}), 1.18 \text { (MDD) }\end{array}$ & \\
\hline rs4765913 & $\begin{array}{l}\text { BPD; GWAS; Combined analysis } \\
\text { of BPD dataset and that of SZ } \\
\text { dataset also showed significant } \\
\text { association with both the disorders } \\
\text { combined }\end{array}$ & $\begin{array}{l}11977 \text { BPD, } 51672 \text { controls } \\
\text { controls }^{a}\end{array}$ & $\begin{array}{l}p=1.52 \times 10^{-8}, \mathrm{OR}= \\
1.14\end{array}$ & $\begin{array}{l}\text { Sklar et al. } \\
\text { (2011) }\end{array}$ \\
\hline rs4765905 & $\begin{array}{l}\text { Combined analysis of SZ and BPD; } \\
\text { GWAS }\end{array}$ & $\begin{array}{l}16374 \mathrm{BPD}+\mathrm{SZ}, 14044 \\
\text { controls }^{a}\end{array}$ & $p=7 \times 10^{-9}$ & $\begin{array}{l}\text { Ripke et al. } \\
\text { (2011) }\end{array}$ \\
\hline rs 1006737 & Psychotic subgroup of BPD & $\begin{array}{l}\text { Family analysis; } 158 \\
\text { psychotic BPD, } 119 \\
\text { nonpsychotic BPD }\end{array}$ & $p=0.017$ & $\begin{array}{l}\text { Lett et al. } \\
\text { (2011) }\end{array}$ \\
\hline rs 4765905 & SZ; GWAS & 20476 SZ; 36737 controls $^{a}$ & $\begin{array}{l}p=1.23 \times 10^{-8}, \mathrm{OR}= \\
1.09\end{array}$ & $\begin{array}{l}\text { Hamshere et al } \\
\text { (2012) }\end{array}$ \\
\hline
\end{tabular}

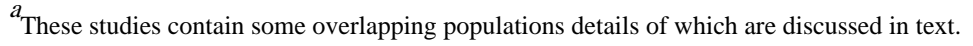


Table 2

\section{Genetic evidence associating CACNA1C with brain structure and function}

Bipolar Disorder (BPD), Schizophrenia (SZ).

\begin{tabular}{|c|c|c|c|}
\hline SNP & Details of Risk/Minor Allele Association & $\begin{array}{l}\text { Population (psychiatrically } \\
\text { normal volunteers unless } \\
\text { otherwise noted) }\end{array}$ & Reference \\
\hline rs1006737 & Increased total brain gray matter volume & 77 adults (British, Caucasian) & $\begin{array}{l}\text { Kempton et al. } \\
(2009)\end{array}$ \\
\hline rs 1006737 & Increased amygdala activity in response to reward & 64 adults (German descent) & Wessa et al. (2010) \\
\hline $\begin{array}{l}\text { rs2051992, } \\
\text { rs2239050 and } \\
\text { rs7959938 } \\
\text { (single LD } \\
\text { block distinct } \\
\text { from } \\
\text { rs1006737) }\end{array}$ & Increased brain stem volume & $\begin{array}{l}585 \text { adults (European, } \\
\text { Caucasian) }\end{array}$ & Franke et al. (2010) \\
\hline rs 1006737 & $\begin{array}{l}\text { Decreased performance on a test of semantic verbal fluency, and } \\
\text { increased activation of the left inferior frontal gyrus as well as } \\
\text { the left precuneus during a separate semantic verbal fluency task }\end{array}$ & 63 adult males (German descent) & Krug et al. (2010) \\
\hline rs 1006737 & $\begin{array}{l}\text { Reduction of activity in the hippocampus, dorsal anterior } \\
\text { cingulated cortex, ventral striatum, superior frontal, and temporal } \\
\text { cortices as well as diminished functional coupling between left } \\
\text { and right hippocampal regions during episodic memory recall; } \\
\text { Risk allele carriers also manifested higher psychopathology } \\
\text { scores for depression, anxiety, obsessive- compulsive thoughts, } \\
\text { interpersonal sensitivity, and neuroticism }\end{array}$ & 110 adults (German descent) & Erk et al. (2010) \\
\hline rs1006737 & $\begin{array}{l}\text { Increased prefrontal activity (lower efficiency) during the N-back } \\
\text { working memory task; Trend for an association with increased } \\
\text { hippocampal activity during emotional memory processing and } \\
\text { increased amygdala activity during an emotional face task; Risk } \\
\text { allele associated with increased brain mRNA expression }\end{array}$ & $\begin{array}{l}\text { N-back study: } 316 \text { adults } \\
\text { Emotional memory processing: } \\
116 \text { adults } \\
\text { Emotional faces task: } 131 \text { adults } \\
\text { mRNA expression: } 161 \\
\text { postmortem brains }\end{array}$ & Bigos et al. (2010) \\
\hline rs1006737 & $\begin{array}{l}\text { Decreased attention-related performance in alerting and orienting } \\
\text { as assessed with a scanner-adapted version of the Attention } \\
\text { Network Test. Trend for an association with reduced neural } \\
\text { activity in the right inferior parietal lobule during orienting and } \\
\text { in the medial frontal gyrus during executive control of attention }\end{array}$ & 80 adults (German descent) & Thimm et al. (2011) \\
\hline rs1006737 & $\begin{array}{l}\text { Increased gray matter density in the right amygdala and right } \\
\text { hypothalamus. Left putamen was smaller in BPD patients } \\
\text { carrying the risk allele }\end{array}$ & $\begin{array}{l}40 \text { healthy adults and } 41 \text { BPD } \\
\text { (British descent) }\end{array}$ & Perrier et al. (2011) \\
\hline rs 1006737 & $\begin{array}{l}\text { Lower extraversion and higher harm avoidance, trait anxiety, and } \\
\text { paranoid ideation scores as assessed via personality } \\
\text { questionnaires, and increased startle reactivity }\end{array}$ & $\begin{array}{l}530 \text { adult males (Greek, } \\
\text { Caucasians) }\end{array}$ & $\begin{array}{l}\text { Roussos et al. } \\
(2011)\end{array}$ \\
\hline rs 1006737 & $\begin{array}{l}\text { Increased right amygdala activation during fear-face recognition } \\
\text { relative to neutral faces; Reduced right ventrolateral prefrontal } \\
\text { cortex activation during emotional processing only in BPD } \\
\text { patients }\end{array}$ & $\begin{array}{l}50 \text { healthy adults; } 41 \text { BPD and } \\
25 \text { first degree relatives (British } \\
\text { descent) }\end{array}$ & Jogia et al. (2011) \\
\hline rs1006737 & $\begin{array}{l}\text { Impaired working memory in schizophrenia patients and healthy } \\
\text { controls, but not BPD subjects }\end{array}$ & $\begin{array}{l}401 \text { healthy adults, } 74 \text { BPD, } 318 \\
\text { SCZ (Chinese) }\end{array}$ & Zhang et al. (2011) \\
\hline rs1006737 & $\begin{array}{l}\text { Increased grey matter volume and reduced corticolimbic/ } \\
\text { frontotemporal functional connectivity }\end{array}$ & 55 adults (American, Caucasian) & Wang et al. (2011) \\
\hline rs1006737 & $\begin{array}{l}\text { Facial emotion recognition impairment in BPD, but not healthy } \\
\text { controls }\end{array}$ & $\begin{array}{l}40 \text { healthy adults (Brazilian) } \\
\text { BPD }\end{array}$ & $\begin{array}{l}\text { Soeiro-de-Souza et } \\
\text { al. }(2012)\end{array}$ \\
\hline rs1006737 & $\begin{array}{l}\text { Effective connectivity from medial frontal gyrus to left putamen } \\
\text { significantly reduced during perception of fearful faces, } \\
\text { particularly in BPD subjects }\end{array}$ & $\begin{array}{l}20 \text { healthy adults, } 20 \text { BPD (in } \\
\text { remission), } 20 \text { unaffected first- } \\
\text { degree relatives }\end{array}$ & Radua et al. (2012) \\
\hline rs1006737 & $\begin{array}{l}\text { Lower emotional lability and stronger resilience (higher sense of } \\
\text { coherence) in women }\end{array}$ & $\begin{array}{l}3793 \text { adults (German) including } \\
1989 \text { women }\end{array}$ & $\begin{array}{l}\text { Strohmaier et al. } \\
(2012)\end{array}$ \\
\hline
\end{tabular}

Prog Neurobiol. Author manuscript; available in PMC 2013 October 01. 